\title{
AGRICULTURA E MINERAÇÃO, UMA COEXISTÊNCIA DIFÍCIL. AS MINAS DO VALE DO VOUGA E AS COMUNIDADES DO VALE DO RIO ÁGUEDA, 1889-1924*
}

\author{
Francisco Vitorino ${ }^{* *}$
}

\begin{abstract}
As Minas do Vale do Vouga, localizadas na freguesia de Talhadas, Concelho de Sever do Vouga, laboraram entre 1889 e 1931. Durante o seu percurso produtivo, mantiveram um conflito com as comunidades agrícolas do vale do rio Águeda, cujos contornos aqui procurámos definir. Se, durante as primeiras décadas, o clamor dos povos, em relação aos efeitos nocivos das águas resultantes da lavagem do minério, foi disperso e localizado, com a mudança de concessionário, depois de 1909, e com o consequente aumento do ritmo de exploração, a contestação tornou-se aberta e sistemática, assumindo, por vezes, a forma de violência. Mercê das contradições do sistema político republicano, o problema da coexistência entre a agricultura e a mineração acabaria por inscrever-se, aqui, no já complexo problema da consolidação do regime, agravando o divórcio existente entre a República e o País.
\end{abstract}

Palavras-chave: Extracção mineira, agricultura, esterilização dos campos, conflito, clientelismo.

** Licenciado em História e professor do Ensino Secundário; mestrando em História Económica e Social Contemporânea, na Faculdade de Letras da Universidade de Coimbra. 


\section{INTRODUÇÃO}

O complexo problema das relações entre a indústria mineira e o meio rural envolvente, sobretudo na perspectiva do impacto ambiental sobre a propriedade agrícola, encontra-se ainda, em grande parte, por estudar. Durante décadas, não só as minas e os mineiros foram quase esquecidos pelos historiadores portugueses, como também o interesse pelas questões ambientais, na perspectiva do impacto ecológico da actividade mineira, praticamente não existiu. Só nos últimos anos, à medida que se vem acentuando o desenvolvimento industrial e a exploração dos recursos, tem vindo a crescer a consciência de que um desenvolvimento mineiro verdadeiramente sustentado deve incluir uma componente ambiental (Oliveira, 1997: 3-25). Do ponto de vista da historiografia da indústria mineira, o caminho já percorrido por uma nova geração de investigadores permite-nos augurar um futuro promissor. Os trabalhos de Paulo Guimarães, João Carlos Garcia, Helena Alves, Idorindo Rocha, António Vilar, J. P. Avelãs Nunes, entre outros, constituem já importantes contributos para o estudo da mineração portuguesa.

$\mathrm{Na}$ realidade, a coexistência entre a indústria mineira e o universo rural envolvente nem sempre foi pacífica, sendo as minas frequentemente vistas como uma ameaça real à ordem instituída. Para além da conflitualidade social inerente ao desenraizamento de muita da mão-de-obra que emprega, a indústria mineira encerra motivações dificilmente harmonizáveis com um mundo rural e agrícola, ritmado por interesses por vezes diametralmente opostos. As normas reguladoras da relação entre concessionários e proprietários, apesar de tentarem estabelecer uma comunhão de interesses, nem sempre foram suficientes para dissipar as tenções latentes, inscrevendo-se, muitas vezes, nas contradições do próprio sistema político. O lançamento nos rios das águas provenientes da lavagem do minério e da lixiviação das "entulheiras", ou mesmo o avanço das galerias para zonas exteriores aos limites das concessões, foram, desde sempre, motivo para conflitos entre a propriedade mineira e a propriedade superficiária.

Uma das premissas clássicas do direito mineiro consagrava o princípio segundo o qual a propriedade mineira pertencia ao Estado, alienando este o direito de uso e usufruto a particulares (Rocha, 1977; Guimarães, 1994; Rodrigues Júnior, 1921). Na linha da tradição liberal, cabia-lhe o poder de se apropriar do subsolo, como forma de garantir a manutenção do interesse e do "domínio público". A actividade privada constituía, portanto, uma questão de interesse colectivo. A dificuldade estava, contudo, na harmonização de ambos os interesses, quando se colocava o inevitável problema dos prejuízos causados a terceiros. 
Durante muito tempo, procurou-se disciplinar os efeitos da lavra de minas pelos princípios da responsabilidade civil. No entanto, atendendo ao facto de a exploração subterrânea ser uma «empresa de audácia excepcional e um desafio corajoso às forças da natureza», corria-se o risco de um grande número de prejuízos serem atribuídos injustamente (Rodrigues Júnior, 1921: 183). Daí que, com o tempo, tenha vindo a afirmar-se o princípio segundo o qual a responsabilidade pelos danos causados devia ser independente da existência ou não de culpa. Foi, de resto, essa a doutrina que inspirou os principais diplomas que tutelaram a exploração mineira ao longo da segunda metade do século XIX, consagrando o princípio da indemnização como o grande mecanismo regulador de conflitos.

O problema do impacto ambiental, resultante da actividade mineira, não se resumia ao âmbito agrícola. O desaparecimento do peixe dos rios, um meio de sobrevivência nuclear ou, por vezes, complementar, para as populações ribeirinhas, ea, frequentemente, o primeiro sinal da catástrofe. As descargas de águas sulfatadas resultantes da lavagem do minério ou as próprias escorrências das águas das chuvas, através da lixiviação dos entulhos, provocavam graves prejuízos às comunidades locais vizinhas: em período de cheias, porque depositavam o «veneno» nas terras; durante a estiagem, porque a necessidade de regas levava à morte lenta das culturas.

Em Aljustrel e em S. Domingos, desde muito cedo se fizeram sentir as queixas dos povos contra os potentados mineiros (Guimarães, 1989; 1994). Mas foi no Distrito de Aveiro, onde a complementaridade da pequena exploração agrícola com as actividades da pesca tinha raízes seculares, que os protestos mais se fizeram ouvir. Dos povos vizinhos do Caima, passando pelas populações residentes nas margens do Vouga, aos pescadores da Murtosa, inúmeras são, ao longo de décadas, as queixas contra os prejuízos causados pelas minas do Palhal, Carvalhal, Telhadela e Pena, no Concelho de Albergaria-a-Velha, do Braçal, no Concelho de Sever do Vouga, ou do Pintor, no Concelho de Oliveira de Azeméis. Apesar de o número de minas em actividade ser relativamente escasso nas primeiras décadas deste século (Rodrigues Júnior, 1921: 30), realidade que, aliás, se inscrevia na continuidade do que vinha acontecendo desde o final do período monárquico, a especificidade técnica e económica do sector levava a que tardassem as soluções para obviar ao problema da poluição das águas e da esterilidade dos campos.

O caso presente é, do ponto de vista da difícil coexistência entre a agricultura e extracção mineira, um bom exemplo, já que é marcado por uma longa batalha entre as comunidades do vale do Rio Águeda e as empresas concessionárias das Minas do Vale do Vouga que se prolongou até à paralisação da actividade, em 1930. Ainda que, por dificuldades de espaço, 
não possamos analisar exaustivamente todos os seus contornos, procuraremos, num exercício de síntese, acompanhar o percurso e a maturação de um conflito que, no limite, culminaria num levantamento popular violento na madrugada de 28 de Junho de 1924.

\section{AS MINAS DO VALE DO VOUGA: OS PRIMEIROS CONTORNOS DE UM PROBLEMA}

As minas do Vale do Vouga, vulgarmente conhecidas por "Minas das Talhadas", localizadas a cerca de duas dezenas de quilómetros a montante de Águeda, fizeram sentir os seus efeitos nas águas dos rios Águeda e Alfusqueiro. Trata-se de um conjunto de sete concessões, seis das quais implantadas na Freguesia das Talhadas, Concelho de Sever do Vouga, e uma, a do "Vale do Vau", na Freguesia do Préstimo, Concelho de Águeda. São elas, de Oeste para Este: "Vale do Vau", "Lomba da Fonte da Serra", "Cabeço da Macieira", "Vale do Bicho", "Vilarinho", "Porto de Vilarinho" e "Avide" (Mapa anexo I) ${ }^{1}$.

Da mina do "Cabeço da Macieira" 2 situada no contraforte da margem esquerda do ribeiro de Santos, afluente do Alfusqueiro, extraía-se a galena argentífera, com alguma percentagem de prata, e da mina do "Vale do Bicho" ${ }^{\prime 3}$, na margem direita do mesmo ribeiro, um filão misto de calcopirite e galena, sendo esta em menor quantidade.

Logo após os primeiros anos de exploração, os efeitos nocivos das águas das minas traduziram-se no aparecimento de alguns peixes mortos no rio Águeda, facto que terá motivado a reacção do administrador substituto do Concelho, João Freitas de Melo, em ofício enviado ao governador civil de Aveiro, a 16 de Agosto de $1892^{4}$. Queixa-se de que as águas da lavagem do minério «têm produzido a destruição de muito peixe, o qual se tem encontrado morto à flor da água em quantidade tal que se tem aproveitado para adubos agrícolas». E, ao longo da exposição, é aventada já a probabilidade de as águas, contendo «sais de cobre e de chumbo», poderem vir a ser prejudiciais à agricultura quando, «transbordando, em virtude de cheias de Inverno, depositarem nas terras agricultadas grande quantidade daqueles princípios, tornando-as estéreis, como já há alguns anos aconteceu nos campos do rio Vouga com as águas das lavagens das minas do Palhal, Carvalhal e Telhadela».

Também o periódico Independência de Águeda (7/8/1915) faz referência a uma carta dirigida pelo administrador do Concelho ao governador civil de então, em 6 se Setembro de 1901, onde dava conta das diligências que recebera da parte de uma «comissão de proprietários e lavradores» que lhe 258 
terão vindo expor os prejuízos causados pelas minas nos campos marginais, sobretudo àqueles que são obrigados a usar as águas para alimentar os gados. Segundo o documento, os terrenos, banhados pelas águas inquinadas de «princípios tóxicos» das lavagens do minério, teriam vindo a aumentar progressivamente o seu grau de esterilização, deixando já de produzir «feijão e abóboras» e provocando uma significativa quebra na produção de milho.

Apesar da reacção das autoridades, até ao final da Monarquia as queixas dos povos em relação ao estado das águas são dispersas e localizadas, não pondo em causa o equilíbrio das relações entre proprietários e concessionários. Se, por um lado, o grau de exploração foi relativamente modesto durante as duas primeiras décadas, por outro, as autoridades locais progressistas não se livraram da acusação de, durante anos, terem dado protecção política às empresas concessionárias. Depois de 1910, a imprensa republicana não se cansará de denunciar estas cumplicidades, para quem o Partido Progressista local terá protegido um dos seus membros com interesses ligados às minas ${ }^{5}$. Na verdade, embora se tenha equacionado o problema pouco depois do início da laboração, nenhum movimento organizado se constituiu, capaz de mobilizar as populações contra os interesses das minas. E, de facto, compulsada toda a documentação camarária existente, em particular as actas da Câmara Municipal de Águeda, não se detectou qualquer tomada de posição da edilidade contra a esterilização dos campos.

Será, efectivamente, após o 5 de Outubro daquele ano, mercê de um novo estilo de intervenção cívica por parte das elites republicanas e do ingresso da questão na conflitualidade política local, que a contestação assumirá um carácter contínuo e regular. E, mesmo assim, teríamos de esperar pelo impacto da I Guerra Mundial para que a questão das subsistências e a progressiva escassez do milho exacerbassem os protestos.

Tendo obtido a concessão do "Cabeço da Macieira", em 1909, e do "Vale de Bicho", em 1913, a nova empresa viria imprimir um novo ritmo de exploração às minas. Foi introduzido um sistema de aproveitamento da força motriz da água do rio Alfusqueiro para a produção de energia eléctrica, o que viria a permitir accionar os aparelhos de ventilação e iluminar o interior das galerias. Foi construída uma estrada que passou a ligar as minas à povoação de A-dos-Ferreiros, num primeiro troço, e à Mourisca, próximo de Águeda, num segundo troço, facilitando assim o escoamento do minério. Para essa construção, beneficiou a empresa do serviço braçal devido ao Município pelas povoações mais próximas, bem como da venda de terrenos baldios por parte da Câmara Municipal de Águeda, denotando um espírito de cooperação e uma fé num progresso material que nada faziam prever o agravamento das relações que, posteriormente, viria a verificar-se $\mathrm{s}^{6}$. Para o transporte do 
minério, a empresa adquiriu um camião a vapor que permitia deslocar até 5 toneladas de mineral até ao caminho-de-ferro ${ }^{7}$. Com a entrada em funcionamento do ramal de Águeda do caminho-de-ferro do Vale do Vouga, ligando Aveiro a Espinho ${ }^{8}$, o transporte do minério deixou de fazer-se por animais de tiro até ao cais de Pessegueiro (Sever do Vouga), no rio Vouga, passando a utilizar a estação da Mourisca e, até, o cais de Águeda.

$\mathrm{O}$ maior dinamismo introduzido na exploração, traduzido num aumento significativo da produção de minério, levou a um crescimento gradual do teor de acidez das águas dos rios. Com efeito, em Janeiro de 1916, no decurso dos trabalhos da comissão de avaliação dos prejuízos das águas das minas nos campos de Águeda, a cujo relatório mais adiante nos referiremos, foram convidados a prestar declarações alguns agricultores que corroboraram esta mesma ideia ${ }^{9}$. Enquanto o peixe dos rios Alfusqueiro e Águeda, bem como a flora aquática, haviam começado a escassear há cerca de 18 anos, as quebras de produção de feijão só foram notadas três anos depois, nos terrenos próximos da ponte de Bolfiar, e seis anos depois nos campos mais próximos de Águeda. Quanto ao azevém e ao milho, os últimos dois anos tinham sido aqueles em que mais se notara os efeitos nefastos das águas das minas. $\mathrm{Na}$ verdade, a mobilização popular e o alastramento da contestação às populações residentes, a jusante de Águeda, crescerá na correlação directa da diminuição da produtividade dos campos. Só assim se compreende a relativa dispersão e fragilidade dos protestos no período anterior a 1910. Independentemente da provável protecção de que gozassem os anteriores concessionários, a verdade é que a relativa gravidade do problema, durante os primeiros anos, parece, em parte, justificar a tolerância mantida.

A questão chega pela primeira vez ao Parlamento pela voz do deputado unionista Moura Pinto, eleito pelo círculo de Aveiro. Na sessão de 10 de Abril de 1913, a propósito do debate parlamentar sobre os abusos das empresas mineiras em Aljustrel e no vale do Sado, o deputado aveirense pediu providências contra a situação em que se encontravam os campos atravessados pelo rio Águeda. Ao longo do ano seguinte, caberá à imprensa local, com particular destaque para a republicana, a tarefa de não deixar cair no esquecimento a questão das minas. Apesar do autismo dos poderes públicos, ainda se aguardava uma resposta conciliadora para o complexo problema. No entanto, com o tempo, a conciliação dará lugar ao radicalismo. 


\section{DA CONCILIAÇÃO À CRISE: O PRIMEIRO LEVANTAMENTO POPULAR CONTRA AS MINAS}

Durante os primeiros anos do novo regime, toda a confiança era depositada na acção dos governos republicanos. Numa altura em que ainda se alimentava a esperança de que a exploração mineira e a actividade agrícola dos povos ribeirinhos poderiam coexistir, acreditava-se que as minas podiam constituir um importante factor de dinamização económica local e regional. A inflação registada no preço dos terrenos próximos da exploração impunha-se aos olhos das populações como um factor promissor de crescimento e de progresso económico. «As minas das Talhadas parecem prometer um grande futuro», podia ler-se no periódico Independência de Águeda, a 16 de Setembro de 1911. A própria visão estratégica e espírito de cooperação revelado pela Câmara Municipal de Águeda, ao aceder à proposta da Companhia concessionária para abrir um caminho até à povoação de Arrancada, beneficiando de terrenos baldios e do serviço braçal dos povos limítrofes, leva-nos a concluir que a perspectiva do poder local, em matéria de desenvolvimento, passava pelo acolhimento de capitais provindos das minas ${ }^{10}$.

Nos anos seguintes, coube à imprensa de feição republicana a tarefa de colocar a questão na ordem do dia. Porém, não só a consciência cívica dos povos não estava amadurecida, como também os efeitos catastróficos da I Guerra Mundial não se haviam ainda feito sentir no quotidiano das populações. É na Primavera de 1915 que começam a antever-se tempos particularmente difíceis. Nesse ano, os problemas da carestia de vida, do açambarcamento e da escassez dos géneros de primeira necessidade pareciam querer articular-se com uma colheita previsivelmente diminuta. $\mathrm{O}$ mês de Março marca o início de uma presença constante, na imprensa local, das referências à carestia de vida e à escassez dos géneros ${ }^{11}$.

A 4 de Junho de 1915, uma comissão composta por algumas das principais figuras republicanas locais, entre as quais Manuel Ribeiro Alegre (habitualmente referenciado como Manuel Alegre), ex-deputado democrático e governador civil de Santarém, e Eugénio Ribeiro, futuro governador civil de Aveiro, reúnem-se com o ministro do Fomento, a quem expõem, de forma exaustiva, o problema. Estávamos em vésperas de eleições e o assunto era, naturalmente, motivo de aproveitamento político. O próprio deputado João Elísio Sucena, uma das principais figuras do republicanismo radical local, seria eleito no pressuposto de que, no Parlamento, defenderia esta causa. E, de facto, em inícios de Julho desse ano, a questão volta ao Parlamento pela sua voz. O deputado profere um eloquente discurso através do qual chama a 
atenção para as consequências económicas do problema, numa comunidade onde o milho é a «base da alimentação pública» ${ }^{12}$. Referindo-se ao quadro legal vigente e reportando-se ao que se passa noutros países, o orador defende uma regulamentação mais apertada no que diz respeito aos prejuízos provocados a terceiros pela lavra de minas, devendo o governo, em casos extremos, retirar a licença de exploração às empresas prevaricadoras ${ }^{13}$.

Nos meses seguintes, a pressão sobre o Governo de José de Castro seria enorme, dando origem à elaboração de um relatório que procurava definir, pela primeira vez, os contornos técnicos do problema. Procura distinguir a questão das águas resultantes da lavagem do minério, daquelas que, por acção das chuvas, se infiltram nos enormes montes de escórias, ainda muito ricas em cobre, acabando por se inquinar também. E conclui que, se em relação àquelas a intervenção é possível, no caso destas «não há, de momento, remédio».

À medida que os resultados políticos iam aparecendo, um novo conflito, até então latente, no seio do combate político local, começava a despontar. Os maiores proprietários, politicamente comprometidos com a oposição conservadora e, até aqui, expectantes, começavam a demarcar-se de tais conquistas e a disputar a liderança da oposição às minas. Enquanto a elite republicana radical tentava atrair a questão para o "terreno institucional", mantendo fechado o círculo constituído pela Comissão Executiva da Câmara Municipal, Governo Civil, Parlamento e Governo, as forças monárquico-conservadoras constituíam-se como grupo de pressão independente, por forma a desvalorizar os esforços desenvolvidos e os resultados obtidos. A 25 de Julho de 1915, por iniciativa de um conjunto de personalidades notáveis da vila, liderado pelo Conde da Borralha, nasce a Comissão de Defesa dos Campos de Águeda «com poderes para estudar os meios a empregar no sentido de se obstar à continuação dos gravíssimos prejuízos causados pelas Minas das Talhadas» ${ }^{14}$.

A criação da Comissão, para além de corporizar uma nova frente de batalha e agudizar a vertente política da oposição às minas, constituiu uma importante alteração estratégica na supervisão dos trabalhos de acompanhamento e de avaliação da sua acção poluente. Socorrendo-se da posição oficial do engenheiro agrónomo, José Tavares da Silva, Chefe dos Serviços de Fomento Agrícola do Norte, natural da Freguesia de Espinhel e com interesses ligados aos campos afectados, os proprietários fazem deslocar a tutela do processo da Direcção Geral de Obras Públicas e Minas e da Circunscrição Mineira do Norte, para os Serviços Agrícolas.

$\mathrm{Na}$ verdade, alguns dos relatórios já produzidos por técnicos daquela Circunscrição tendiam a ilibar a empresa concessionária, tentando provar que a esterilização dos campos se devia mais à «lixiviação dos entulhos 
originados pela empresa concessionária anterior», do que às águas resultantes da lavagem do minério ${ }^{15}$. Indignados, os povos que se encontravam a jusante da ponte de Águeda, em particular os da freguesia de Espinhel, dirigem um extenso e veemente protesto ao ministro do Fomento, onde procuram definir o impacto económico local da progressiva esterilização dos campos. Rejeitam liminarmente a ideia de que os estragos sejam devidos aos entulhos depositados nas encostas, pois, se assim fosse, os estragos que, desde 1914, se faziam sentir com mais acuidade, deveriam ter-se manifestado há mais tempo. Relativamente à reparação dos danos, o documento rejeita o princípio da indemnização total, como era habitual proceder por parte das empresas, de acordo, aliás, com a legislação em vigor (Guimarães, 1989: 21-24). É que, sendo a exploração intensiva do solo a base da sobrevivência dos povos, a indemnização total pelos prejuízos causados nunca rendibilizaria as mais-valias de um solo produtivo. Assim, para os proprietários, a indemnização deveria ser progressiva, como progressivos eram os prejuízos ${ }^{16}$.

$\mathrm{O}$ protesto entrava assim numa nova fase, assumindo como principal exigência a constituição de uma comissão técnica que produzisse um estudo sistemático que assentasse em bases científicas credíveis. No início do mês de Setembro de 1915, a nova comissão, presidida por Tavares da Silva, dava início ao estudo das causas dos prejuízos e à sua avaliação. Dos trabalhos da comissão resultaria um relatório que, no essencial, reconhecia a justiça das reclamações e a responsabilidade das minas na esterilização dos campos ${ }^{17}$. A análise às águas revelava a existência de ácido sulfúrico, sulfatos e cloretos, numa extensão de cerca de $25 \mathrm{~km}$ ao longo do curso do rio Águeda (Mapa anexo I). A área total dos terrenos atingidos rondava os 182 hectares, sendo a quebra de produção do ano de 1915 de 40\%, em relação à média dos anos anteriores ${ }^{18}$.

Do ponto de vista técnico, a companhia dispunha já de uma modelar instalação destinada à lavagem, escolha e trituração do minério (Foto, anexo II). Todavia, apesar de tecnologicamente avançado, o sistema deixava muito a desejar relativamente ao saneamento de águas e lamas. À saída dos tanques de decantação as águas vinham turvas e carregadas de sulfuretos e de cloretos, sendo as lamas depositadas nas encostas sobranceiras ao ribeiro de Santos e, por isso, expostas à acção lixiviadora das águas pluviais. Parecia, assim, evidente, ao contrário do que pretendiam fazer crer os relatórios anteriores, que o esforço desenvolvido pela empresa no sentido de proceder ao tratamento das águas e das lamas resultantes da lavagem do minério não passava de uma quimera. A própria "cementação", um processo de produção de concentrados (cemento) por via húmida, já há muito utilizado nas grandes explorações alentejanas (Guimarães, 1989: 80; 140-144), não terá tido grande aceitação ${ }^{19}$. 
Em face das conclusões do relatório ${ }^{20}$, a empresa reconhecia a justiça das reclamações e assumia a responsabilidade do pagamento de indemnizações aos proprietários. Assim, comprometia-se a: a) realizar os trabalhos necessários para tornar inofensivas as águas lançadas no rio; b) pagar aos proprietários reclamantes, como indemnização, $60 \%$ do total dos prejuízos avaliados; c) assumir o pagamento anual de 100 toneladas de cal para, durante um período de três anos, serem aplicados nos terrenos com vista à neutralização da acidez.

A concretização do acordo com a empresa concessionária significou, à primeira vista, uma importante vitória dos proprietários dos campos de Águeda; a indemnização fora, desde sempre, uma das suas principais reivindicações. No entanto, os termos do acordo levantavam, desde logo, um conjunto de questões que, a breve trecho, se revelariam importantes. Em primeiro lugar porque, ao contrário do que sempre se considerara justo, a indemnização era global e não progressiva, ficando o pagamento de uma nova indemnização dependente de prova de incumprimento no processo de neutralização das águas. Ora, não tendo ficado previsto qualquer mecanismo oficial de controlo ou de acompanhamento da execução dos compromissos assumidos pela empresa, muito dificilmente se provaria o seu incumprimento. A invocação da lei geral e a inscrição dos seus princípios no alvará de concessão não era, como nunca fora, razão suficiente para obrigar os concessionários a cumprirem as suas obrigações em matéria de prejuízos.

Nos meses subsequentes à assinatura do acordo, a recentemente constituída Companhia de Minas do Vale do Vouga, sociedade anónima de responsabilidade limitada $^{21}$, parecia revelar um significativo empenho no cumprimento dos compromissos assumidos. Foram construídos canais revestidos a pedra calcária e um tanque de neutralização, onde eram reunidas as águas provenientes da lavaria e do esgoto da mina, às quais era adicionado «jacto de leite cal» preparado em tanques escavados na encosta por meio de um agitador mecânico. Além disso, foram abertas valas no sopé das duas vertentes sobranceiras ao ribeiro de Santos, por forma a evitar as escorrências provenientes das "entulheiras". Foi ainda construído um aqueduto ao longo do referido ribeiro, a fim de impedir a incorporação das águas sulfatadas no rio Alfusqueiro.

Todavia, os efeitos dos trabalhos de neutralização das águas tardavam em chegar. Em Outubro de 1916, quatro meses depois do prazo acordado para a conclusão dos trabalhos, o Chefe da Comissão Técnica, engenheiro Tavares da Silva, em visita às minas, concluía que as águas do rio continham ainda alguma acidez. No entanto, a crer no alvitre da referida comissão e a cumprirem-se as disposições por ela aconselhadas, o período de tempo julgado necessário para que as terras readquirissem o seu potencial produtivo 
era de três anos. Além disso, tendo as regas sido feitas, durante o Verão de 1916, ainda com águas ácidas, era de esperar um agravamento da esterilização dos campos ${ }^{22}$. E, de facto, de tal forma a situação se afigurava difícil que, em Novembro de 1916, o preço do milho subiu, vertiginosamente, de 800 para 1400 réis. Na verdade, perante o quadro sombrio que se avizinhava, só a expectativa em relação ao compromisso assumido pela empresa e ao consequente rejuvenescimento dos terrenos poderia manter os povos em silêncio.

É sob a eminência da fome e a certeza da Guerra que se inicia, em Águeda, o ano de 1917. Se a má colheita de 1916 criara problemas gravíssimos às classes populares, os açambarcamentos dos géneros de primeira necessidade e a expectativa dos proprietários em aguardar por melhor preço, tornaram mais complicada a situação durante os primeiros meses do ano seguinte, fazendo disparar o preço do milho. A realidade estrutural do País em matéria de dependência externa era, de resto, bem conhecida. Portugal tinha uma balança comercial claramente deficitária, tendo de recorrer, anualmente, no mercado externo, a grandes quantidades de cereais, carne e outros produtos alimentares básicos (Telo, 1977: 101 e ss.; Marques, 1991: 169-185). A falta de transportes, a dificuldade em comprar no exterior e o encarecimento dos bens, piorando a já difícil situação da agricultura, aliavam-se agora à quebra da produção dos campos.

Para fazer face à crise que se avizinhava, a Câmara Municipal de Águeda requisitou 60 toneladas de milho exótico, na expectativa de, por um lado, equilibrar os preços e, por outro, garantir as subsistências até, pelo menos, ao início das novas colheitas. Todavia, em finais de Janeiro, queixava-se já o presidente da Comissão Executiva da Câmara que o milho exótico estava a ter tal procura que temia já não chegar, sequer, até meados de Março. Na realidade, num Concelho que, à época, contaria cerca de 25 mil habitantes e em que a base da alimentação recaía no milho, tornava-se difícil suprir as necessidades recorrendo, exclusivamente, a milho exótico.

É neste contexto que, de forma expectante, se aguardam os efeitos das medidas tomadas para neutralizar as águas das minas. No entanto, no momento em que se preparavam as novas sementeiras, um novo problema vinha adensar a gravidade dos outros dois já conhecidos. A juntar ao desaparecimento do peixe e à continuação da acção nociva das águas ácidas sobre as culturas, começa a colocar-se a questão do assoreamento do rio e dos campos, mercê da trituração do granito com vista ao aproveitamento exaustivo do minério. Se a neutralização das águas e a aplicação de cal, conjugada com estrumações abundantes, poderia vir a restituir a antiga fertilidade às terras, o assoreamento dos campos vinha complicar o já difícil consenso em torno da laboração das minas. Em finais de Abril de 1917 reúne 
o Senado Municipal, onde é proposta a constituição de uma grande "Comissão Regional" para se deslocar a Lisboa, a fim de fazer sentir ao governo o descontentamento que se vive no Concelho.

Numa exposição enviada ao ministro do Fomento, Herculano Galhardo, em inícios de Maio de 1917, era denunciado o incumprimento, por parte da Companhia das Minas, do contrato realizado com os proprietários, no qual se comprometera a neutralizar as águas a partir de 30 de Junho de 1916 e, em face disso, era fixado o prazo de um mês para que se vissem resultados palpáveis na solução da questão. Reconhecia-se, pela primeira vez, a incompatibilidade absoluta entre a actividade agrícola e a extracção mineira e, numa atitude peremptória, defendia-se o encerramento das minas. Baseando-se no velho princípio da superioridade do bem colectivo sobre o individual, o documento revelava um radicalismo de posições, inédito até ao momento. De um lado, encontra-se o Concelho «com os seus 25 mil habitantes» e, do outro, «uma simples empresa, constituída, quando muito, por meia dúzia de cidadãos ricos» que, do ponto de vista da produção de riqueza, em nada se compara à importância da riqueza dos campos prejudicados. «Serão os interesses dos proprietários dos campos do Águeda e do Alfusqueiro conciliáveis com os da empresa das Minas?», questiona a Soberania a 30 de Maio. «Se o forem tanto melhor. Se não forem tanto pior para a referida empresa, pois que nenhum governo poderá consentir a laboração de umas minas que levem a intranquilidade e o desespero a uma grande região ameaçada de miséria».

Decerto os poderes públicos teriam consciência desta conflitualidade latente, mas o encerramento das minas, a única solução verdadeiramente eficaz, não era bem acolhido, nem do ponto de vista económico, nem do ponto de vista estratégico. A harmonia entre o interesse individual e o bem público, no que diz respeito ao aproveitamento do subsolo, era da responsabilidade do Estado. Assentava na cobrança do imposto proporcional que era calculado sobre o rendimento líquido obtido pelos concessionários anualmente e estabelecido, grosso modo, sobre uma percentagem de $3 \%$ a $4 \%$ sobre o valor dos minérios à boca da mina. Uma das principais cláusulas que incorporava os alvarás das empresas previa a obrigatoriedade de manter as minas em lavra activa, sob pena de cessação ou de transferência da concessão. Ora, apesar de o País pouco lucrar com o desenvolvimento mineiro, já que a maior parte do minério era exportado, os poderes públicos procuraram sempre harmonizar o interesse colectivo, consubstanciado na obtenção do imposto, com o interesse individual, assente na propriedade agrícola. O dilema explica, em grande parte, a atitude titubeante e contraditória dos governos que, sucessivamente, passarão pelo problema ${ }^{23}$. 
A esperança das populações na difícil coexistência entre a mineração e a agricultura, chegara ao fim. A 18 de Maio de 1917, corre, em Águeda, o boato de que uma comissão de engenheiros havia visitado as minas para colher amostras, tendo a empresa sido avisada de véspera e procedido à neutralização das águas, com o objectivo de despistar o resultado das análises. Como se isso não bastasse, os engenheiros terão ainda viajado de Aveiro para as minas num automóvel posto à sua disposição pela Companhia. A reacção não se fez esperar. Na noite de 20 para 21 de Maio, o povo, indignado, investiu contra umas «barricas de minério» que se encontravam no cais da Vila. «Em poucos minutos, eram estilhaçadas e lançadas ao rio, vazias» ${ }^{24}$. Durante toda a semana os ânimos estiveram exaltados. A 24 de Maio chegava a Águeda o engenheiro Monteiro de Barros, então director técnico das minas, sendo logo rodeado de muitos populares que dele se abeiraram para protestar. Perante a reacção enérgica do visado, o povo exaltou-se e logo ali o quis linchar. Tocam os sinos a rebate e um grande número de pessoas, vindas das freguesias vizinhas, voltam a juntar-se no largo 5 de Outubro, dispostas a provocar distúrbios. Debaixo de uma «pilha de lenha» foram então encontradas mais algumas barricas de minério e um significativo número de «rails, sistema decauville» que, imediatamente, foram lançados ao rio. Entretanto, em movimentação organizada, o povo dirigiu-se para a Mourisca, onde a empresa possuía também alguns interesses. Aí foram destruídas 20 barricas de minério que estavam no cais da estação, bem como lançado fogo ao armazém contíguo, pertencente às Minas. Arderam 1500 barricas de minério e um camião que aí se encontrava.

Apesar de há muito latente, a reacção violenta dos povos não deixa de levantar algumas questões, sobre as quais importa reflectir. Quando pouco tempo antes ainda se realçara o bom andamento das obras com vista à neutralização das águas, como explicar a repentina alteração do comportamento das populações? Por outro lado, tendo os povos aguardado, estóica e pacificamente, por uma solução, como justificar que, já com ela em marcha, não tenha sido possível esperar pela recomposição dos solos?

O relatório enviado à Repartição de Minas, a 30 de Maio de $1917^{25}$, e que resultou da visita às minas da comissão de engenheiros que provocou a ira popular, para além de negar liminarmente a tese de incumprimento do contrato que motivou os primeiros protestos a partir de Abril, reafirma a ideia de que, embora se mantivesse o problema da infertilidade dos solos, como aliás era previsível, todos os trabalhos projectados e todas as soluções preconizadas se encontravam em curso. É certo que, como já referimos, não era a primeira vez que a circunscrição Mineira do Norte tomava posições próximas das minas. No entanto, se tivermos em conta as vistorias realizadas 
pelo engenheiro Tavares da Silva, entre Julho e Outubro de 1916, e que, ainda a 2 de Dezembro do mesmo ano, o periódico Independência de Águeda, corroborando estas informações, afirmava que as obras tendentes à completa neutralização das águas prosseguiam em grande actividade, somos levados a supor que a tese do incumprimento do contrato pode não explicar, por si só, os acontecimentos de Maio.

$\mathrm{Na}$ realidade, não tendo sido previsto no acordo assinado, entre os proprietários e as empresa concessionária, um sistema de acompanhamento e monitorização dos trabalhos e, atendendo a que a substituição do antigo director técnico, Louis Rochet, em finais de $1916^{26}$, pode ter levado a um abrandamento do rigor dos procedimentos a seguir com vista à neutralização das águas, era possível vir a verificar-se algum atraso na visibilidade imediata dos seus efeitos. Contudo, tendo sido a imprensa local, desde sempre, a grande voz dos protestos contra as minas, por que manteve absoluto silêncio, entre Dezembro de 1916 e o início das sementeiras do ano seguinte?

Parece poder, assim, concluir-se que a reacção violenta dos povos se inscreve nas crescentes dificuldades criadas pelo aumento do custo de vida e pela escassez dos géneros, facto que se enquadra no crescimento da conflitualidade social registada um pouco por todo o país, ao longo o ano de 1917 (Telo, 1977: 109-131; 1994: cap. II). A má colheita registada no ano anterior e a antevisão do agravamento da situação para ano seguinte, com reflexos directos na subida do preço do milho, tornavam incomportável o já complexo problema das «subsistências», em consequência do estado da economia portuguesa no pico da Guerra. Durante a destruição dos bens da empresa, na Mourisca, o povo gritava: «temos fome, temos fome». 


\section{AS CONTRADIÇÕES POLÍTICAS E A OPOSIÇÃO ÀS MINAS}

Um dos aspectos marcantes do conflito que opôs as comunidades do vale do rio Águeda às Minas do Vale do Vouga foi o relacionamento sinuoso e contraditório que manteve com o acérrimo combate político local. Embora nunca verdadeiramente assumido, o aproveitamento político desta questão foi uma constante ao longo do período de laboração das minas e, diremos mesmo, esteve sempre subjacente a todas as iniciativas, quer do ponto de vista técnico, quer do ponto de vista estratégico. Praticamente todas as medidas tomadas face ao conflito, mesmo as de carácter legislativo, tiveram a sua origem na influência política das figuras mais proeminentes do espectro político local.

À semelhança do que se passava ao nível do País, também Águeda, após a implantação da República, conheceu uma profunda clivagem política, cujos efeitos se fizeram sentir em todos os aspectos da vida local. Essa clivagem traduzia-se frequentemente por comportamentos e regras de funcionamento clientelar e caciquista, tanto do lado do saudosismo monárquico, como do da elite republicana emergente ${ }^{27}$.

A prevalência do caciquismo político no conjunto do país, mesmo depois de implantada a República, era já prevista pelos próprios republicanos nas vésperas do 5 de Outubro (Valente, 1974; Lopes, 1993; Almeida, 1982, 1991). À definição de cacique já proposta por Oliveira Martins, dividindo-os em proprietários e burocratas, vinha José Barbosa, já nos fins da Monarquia, propor uma outra classificação mais ampla nas páginas da Alma Nacional. Distinguia o caciquismo administrativo, patronal, clerical e ainda o caciquismo propriamente político. $\mathrm{O}$ caciquismo administrativo resultava da captação do eleitorado por meio de obras de utilidade local e melhoramentos públicos; o caciquismo patronal era exercido por certos patrões (Mónica, 1990) que forçavam o voto dos empregados sob ameaças; o caciquismo clerical traduzia-se na influência exercida pela Igreja, sobre as populações analfabetas, em particular das zonas rurais; e, finalmente, o caciquismo político que era afinal o mais estimulado pelo próprio governo - a partir do qual os chefes partidários enviavam aos seus patronos locais as orientações estratégicas, sobretudo em período de eleições.

Também a imprensa de Águeda, logo após a implantação da República, dedicou muitas das suas energias a discutir a questão. Durante os primeiros meses do novo regime, os dois periódicos rivais envolveram-se numa aguerrida polémica, iniciada com o ataque cerrado das novas instituições republicanas ao "antigo" caciquismo local. Tudo começou com a atribulada adesão de muitos elementos do Partido Progressista ao novo regime, cujo 
fenómeno ficou conhecido por "adesivismo" (Lopes, 1993) ${ }^{28}$. Mas a discussão atingiu o auge, quando se procedeu às primeiras rupturas com as heranças do passado. Referimo-nos, a título de exemplo, à destituição de algumas figuras locais dos cargos que ocupavam, à transferência de outras ${ }^{29}$, à retirada dos retratos de Albano de Melo e de seu filho, o Conde de Águeda, da sala das sessões da Câmara Municipal e, sobretudo, à alteração dos nomes de algumas ruas e praças da vila ${ }^{30}$.

A prática do caciquismo era favorecida pelo baixo nível cultural das populações que desconheciam praticamente os mecanismos políticos, sobretudo os mecanismos eleitorais, o que deixava, por vezes, a porta aberta a todo o tipo de acções de corrupção. Era exercida numa pirâmide hierárquica que, numa lógica vertical, coincidia habitualmente com as divisões administrativas: o cacique distrital, por hábito o governador civil, relaciona-se com as chefias partidárias e estabelece a artic ulação entre estas e os influentes concelhios.

Não obstante a mudança de regime, em Águeda o patrocinato político, associado à Regeneração e animado pelos maiores proprietários da região, não perdeu a sua influência clientelar. Apesar das dificuldades de acesso às instituições políticas - que, no plano nacional, foram uma das principais fontes de deslegitimação e de instabilidade da $1^{a}$ República (Lopes, 1993: 11) -, o antigo escol progressista local não deixou de criar problemas à elite republicana, obrigando-a a um constante esforço de consolidação e de legitimação do regime.

A "crise de participação" e a dificuldade da República em absorver os adversários políticos, numa lógica de pacificação, seria responsável, em Águeda, pela constante conflitualidade política vivida entre 1910 e 1926 . É certo que, se a República tivesse concedido aos monárquicos direitos iguais e livre acesso à participação política, o próprio regime correria sérios riscos de sobrevivência. No entanto, a verdade é que o núcleo republicano revelou uma tremenda incapacidade para esquecer ódios antigos e para compreender que a consolidação das instituições passava, em parte, pela integração dos adversários políticos. Ao contrário do que se ia passando no plano nacional, em que as facções mais moderadas do novo regime revelaram alguma dificuldade em suprimir as dependências que prendiam os eleitores aos influentes, aqui a imprensa radical, "afonsista", denunciou ferozmente o cacique monárquico, fechando a porta a qualquer tipo de "adesivismo".

O novo patrocinato ligado aos partidos republicanos, em que sobressaíam profissionais liberais, sobretudo médicos e advogados, funcionários públicos, comerciantes, industriais e, também, um certo número de proprietários rurais, conseguiria reunir uma certa clientela, embora pulverizada em torno das formações resultantes da divisão do velho Partido Republicano. Numa 
palavra, à influência de um caciquismo monárquico substituiu-se, sem dúvida, um caciquismo republicano.

A vida política de Águeda, após o 5 de Outubro de 1910, haveria de polarizar-se em dois grandes sectores. Do lado monárquico, conservador e católico, era a continuação da antiga estrutura clientelar progressista, fervilhando em torno da família do conselheiro Albano de Melo Ribeiro Pinto $^{31}$ e do seu sucessor directo, Manuel Homem de Melo, o Conde Águeda; do lado republicano-democrático, em torno das suas principais figuras: Manuel Alegre, Eugénio Ribeiro, João Elísio Sucena, entre outros ${ }^{32}$. A divisão do Partido Republicano, logo depois do Congresso de 1911, também se reflectiu neste Concelho. No entanto, à semelhança do que se passava a nível nacional, também aqui se impôs o Partido Democrático. Relativamente ao funcionamento das máquinas clientelares podemos afirmar que, com o advento da República, o caciquismo clerical local perdeu muita da sua influência. Todavia, alguns párocos desenvolveram uma intensa campanha contra o novo regime, assumindo mesmo alguma liderança política. É o caso, entre outros, do Padre Óscar de Aguiar, várias vezes membro do executivo municipal e, frequentemente, elemento operacional nas intentonas monárquicas e, até, no conflito contra as minas.

Quanto ao caciquismo político e administrativo, sem dúvida o mais activo, mormente com o agravamento da crise económica e social dos anos da I Guerra Mundial, é sabido que as "moedas de troca" mais compensadoras, sobretudo em termos de apoio eleitoral, eram os empregos e as funções públicas. Porém, não menosprezando esse tipo de oportunidade nos meios locais, por razões de oportunidade política era mais frequente a realização de obras públicas ou benefícios colectivos. No caso de Águeda, destaca-se, sem dúvida, o ramal de Águeda do caminho-de-ferro do Vale do Vouga, cuja concretização muito se deveu à influência e aos "conhecimentos" do Conde de Águeda junto do Governo do Partido Progressista. São de notar também alguns melhoramentos conseguidos durante a vigência dos governos democráticos, como é o caso da continuação das obras do cais das Laranjeiras, da estrada da Castanheira e do Matadouro Municipal, cuja concepção foi objecto de grande controvérsia política ao longo de anos, e que a Comissão Executiva conservadora durante o "consolado sidonista" (5/12/1917-14/12/1918) haveria de abandonar definitivamente.

É neste quadro socio-político que, ao longo do período de laboração das minas, se desenrola o conflito. Durante a fase final da período monárquico, o silêncio quase absoluto das autoridades, em relação ao problema dos campos, parece indiciar, de facto, a teia de relações clientelares existentes no seio das fileiras do Partido Progressista. Contudo, a ser verdade, como não se cansa 
de sugerir a imprensa republicana depois do 5 de Outubro, também não restam duvidas de que, depois dessa data, a questão não deixou de ser utilizada como arma de arremesso político, bem como de integrar a estratégia política republicana, num quadro de afirmação, consolidação e de legitimação do regime.

A imprensa local, um dos suportes privilegiados do combate político, desempenhou um inegável papel na mobilização popular contra a esterilização dos campos. O periódico Independência de Águeda, afecto ao Partido Democrático, não se cansará de denunciar a protecção dada aos concessionários, até à queda do regime monárquico. Acusava o chefe político local, o conselheiro Albano de Melo, de se opor a alguns «protestos ordeiros» dos povos e de, em consequência, ser conivente com os interesses das minas.

A plêiade monárquica, directamente visada nas acusações, detentora de uma visão salutar das relações clientelares intrínsecas ao sistema político, levantou-se em peso em defesa do caciquismo da fase final da Monarquia. Aquando da sugestiva polémica travada na imprensa local logo após o 5 de Outubro, num conjunto de artigos de reacção contra o que considerava ser «o bloco do ódio e da inveja ${ }^{33}$, Mateus Pereira Pinto procurou definir e justificar o caciquismo em Águeda durante o constitucionalismo monárquico. Considerava, então, que alguns indivíduos, «sacrificando o seu descanso e, muitas vezes, os seus interesses, se tinham dedicado ao bem-estar moral e material dos seus vizinhos em cujo espírito despertavam (...) sentimentos de gratidão e de amizade» ${ }^{34}$. Albano de Melo e seu filho, o Conde de Águeda, terão sido os mais distintos representantes dessa geração de caciques.

É nesta linha de pensamento que os homens próximos da família Melo reagirão aos ataques desferidos pela imprensa republicana. Não se compreende, afirmam, como poderia Albano de Melo ter dado protecção política às minas, quando ele próprio era proprietário nos campos de Águeda. «Amigo, embora, de Benjamim de Pinho Camossa, não se lembraria das minas deste, para se esquecer dos terrenos dele» ${ }^{35}$. O que ele não podia, naturalmente, era incentivar os propósitos populares a arrasar as minas, pois poderia ser acusado de instigador do facto. Além do mais, prossegue, o próprio Benjamim Camossa nunca pediu que protegessem os seus interesses nas minas, em detrimento do dos proprietários. Ele abstinha-se até de falar sobre o assunto, pois sentia a animosidade popular, numa altura em que apenas a produção de feijão tinha dado sinais de quebra. A produção de milho era ainda abundante, o que «não admira», pois «era ainda reduzida a exploração...». O clamor dos povos, em protesto contra os malefícios das minas, não se fazia sentir como agora. «Havia até quem duvidasse que elas então os causassem...». O que é facto, conclui, é que «passaram 5 anos 
depois da queda da Monarquia e as minas, nocivas como jamais o haviam sido, laboram à vontade, sem o mínimo obstáculo por parte dos partidos locais do novo regime. Num ano, dada a exploração intensiva, causavam maior dano depois de 1910, do que em 30 anos de exploração, quando pertencentes a Benjamim Camossa» ${ }^{36}$.

Do lado republicano, apesar das indiscutíveis preocupações cívicas, a verdade é que a estratégia delineada em relação às minas teve, quase sempre, objectivos claramente político-eleitorais. A observação atenta do seu comportamento político permite-nos compreender como a fragilidade do regime o levou, em alguns momentos, a socorrer-se de todos os expedientes possíveis para se implantar e consolidar. Pela carga emotiva que, paulatinamente, foi adquirindo, a oposição às minas viria a tornar-se uma excelente mais-valia política, levando a que, até meados de 1915, fosse claramente liderada pelo imprensa republicana radical. Aproveitando o conflito, as forças fiéis ao regime procuraram fazer passar uma mensagem de confiança nas novas instituições, criando uma sensação de proximidade entre o poder e o povo ${ }^{37}$.

A 13 de Abril de 1912, noticiava a Independência que, face à insistência do deputado Manuel Alegre junto do ministro do Fomento, eram dadas ordens à empresa para evitar lançar as águas inquinadas no rio Alfusqueiro, tendo também chegado às minas algum equipamento técnico para «fixação das lamas venenosas». E concluía o jornal, regozijando-se: «a pouco e pouco, sem alardes espalhafatosos, vamos remediando os tremendos prejuízos causados pelos extintos progressistas». No entanto, os anos passavam e as medidas tardavam em chegar. Apesar da disponibilidade revelada pelos sucessivos governos, nem a pressão exercida sobre o governador civil era suficiente para desbloquear o problema e sensibilizar os poderes públicos para a urgência da sua resolução.

O ano de 1915 viria a revelar-se decisivo, do ponto de vista dos interesses dos proprietários de Águeda. Após a queda do Governo de Pimenta de Castro, a 14 de Maio $^{38}$, e já refeitas do impacto causado pela eclosão da Guerra, as "hostes" republicanas voltam ao combate, aproveitando o ensejo da chegada dos democráticos ao poder. Contudo, fazem-no em plena campanha eleitoral para as eleições de 13 de Junho de 1915, assumindo o risco de tal atitude poder vir ser mal interpretada pela oposição ${ }^{39}$. Apesar disso, uma das frases mais repetidas durante a campanha eleitoral era a da necessidade de eleger um deputado de Águeda, o Dr. Elísio Sucena, cuja missão principal era «a de tratar, com toda a brevidade e com todo o cuidado, a questão das minas». O sentido de oportunidade política do periódico afecto ao Partido Democrático permitia-lhe, a 12 de Junho, na véspera das eleições, referir-se à recente reunião com o ministro do Fomento, lembrando que este 
«é um amigo íntimo do Dr. Manuel Alegre e, como tal, há-de acreditar no que lhe foi relatado sobre os prejuízos causados pela minas». Uma comissão constituída por Manuel Alegre, Eugénio Ribeiro e José Gomes da Costa havia sido recentemente recebida pelo ministro Manuel Monteiro.

Era a tentativa clara de pôr em marcha a teia de relações clientelares existentes no interior do Partido Democrático. A conjuntura era propícia e a estratégia daria os seus frutos. Manuel Alegre, uma figura respeitada e influente dentro do partido, estabelecia a ligação entre este, o Governo e a rede clientelar distrital. Embora radicado em Santarém, nunca deixou de se interessar por esta questão e de lhe dar o seu contributo pessoal e político ${ }^{40}$. A 5 de Julho, Eugénio Ribeiro era eleito governador civil de Aveiro, de onde, dias depois, enviava uma extensa representação ao ministro, na qual expunha o estado da contestação à indústria mineira a nível distrital, colocando a tónica, como seria de esperar, no caso de Águeda. E, fechando o círculo, Elísio Sucena, cumprindo nos primeiros dias de Julho a missão que lhe fora confiada durante a campanha eleitoral, profere um interessante discurso no Parlamento, onde denuncia o autismo dos poderes públicos e das minas, face à crescente esterilização dos campos de Águeda ${ }^{41}$.

Após o "ataque" coordenado da "máquina" do Partido Democrático, começaram a aparecer os primeiros resultados práticos. Dias depois do discurso proferido no Parlamento pelo deputado Elísio Sucena, surgem notícias de que elementos ligados às minas terão visitado os campos, a fim de se inteirarem dos estragos provocados.

Face ao protagonismo revelado pelos homens do regime, reagem os sectores mais conservadores, ligados, na sua maioria, ao núcleo monárquico, mas onde pontificavam também alguns evolucionistas. E dessa reacção nasce, a 25 de Julho de 1915, a Comissão de Defesa dos Campos de Águeda que, de alguma forma, vem materializar a real dimensão política do conflito com a companhia das minas. A Comissão assume imediatamente uma liderança alternativa, manifestando o propósito de, num dos dias seguintes, se deslocar às minas a fim de se encontrar com o seu director técnico. E, em resposta, a 2 de Agosto, deslocam-se às Talhadas o governador civil e o administrador do Concelho. Era evidente o esforço desenvolvido por ambas as partes na luta pelo protagonismo político na liderança do conflito.

A nomeação da Comissão Técnica, em pleno Agosto de 1915, ocorre, como vimos, em condições relativamente obscuras e envolta em alguma contradição institucional, redundando na partilha de competências entre a Direcção Geral de Obras Públicas e Minas e a Direcção Geral de Agricultura. A intervenção do então Chefe dos Serviços de Fomento Agrícola do Norte, José Maria Tavares da Silva, também ele proprietário nos campos de Águeda e natural da freguesia de Espinhel, deve ter-se revelado fulcral neste conflito 
de competências, porquanto a celeridade com que a Comissão foi nomeada e enviada para o terreno revela que os trâmites não terão sido os habitualmente seguidos. Senão vejamos: a primeira representação dos proprietários da freguesia de Espinhel ao Director dos Serviços Agrícolas do Norte, cuja primeira assinatura era a de Tavares da Silva, data de 16 de Agosto; cinco dias depois, a 21 de Agosto, já se encontrava no terreno o Delegado Agrícola da $9^{a}$ Secção - Aveiro -, o Eng ${ }^{\circ}$. Vasco de Carvalho. Nunca no tratamento da questão das minas se havia registado semelhante tomada de posição. A transferência de competências da Circunscrição Mineira para os Serviços Agrícolas significou, em última instância, uma vitória no combate às minas, pois os resultados obtidos a partir de agora aproximavam-se, como nunca, dos interesses dos proprietários agrícolas. Os trabalhos de análise e avaliação dos prejuízos respondiam, quase na sua totalidade, às aspirações dos proprietários dos campos de Águeda.

A reacção enérgica dos povos de Espinhel e de Águeda quanto ao teor do "relatório Bensaúde", publicado entretanto, levou a que, a 27 de Agosto, o Director dos Serviços Agrícolas do Norte procedesse ao reforço de meios humanos, por forma a que as avaliações pudessem estar concluídas antes das colheitas de Setembro e, bem assim, do desaparecimento das provas dos prejuízos. Era então constituída a Comissão Técnica. A 3 de Setembro estavam organizadas as instruções, a 9 colhiam-se as amostras das águas nas Minas e a 14 dava-se início aos trabalhos de campo.

Posto isto, podemos concluir que, para além das estruturas clientelares subjacentes ao processo político, quer no plano nacional quer no plano local, também ao nível dos serviços da administração pública, central e regional, era possível encontrar mecanismos de subversão institucional, muitas vezes coniventes com uma certa partidarização e corporativisação das funções governativas. A insuficiência de garantias de imparcialidade da parte dos organismos tutelares das minas, provavelmente mais premiáveis ao lobby mineiro, como pudemos constatar no chamado "relatório Bensaúde", levou os proprietários a socorrerem-se dos Serviços Agrícolas, onde lhes seria mais fácil encontrar uma postura mais consentânea com os interesses da lavoura.

Por outro hdo, ao recair nos Serviços de Fomento Agrícola a tutela da condução dos trabalhos de avaliação dos efeitos das águas das minas nas culturas dos campos, estava consolidada a proeminência da oposição na liderança do conflito. Até ao acordo final com a companhia concessionária, os órgãos do poder local perderam totalmente a sua capacidade de intervenção, assumindo-se a Comissão de Defesa dos Campos como a única interlocutora da parte dos proprietários. De tal maneira se posicionaram em relação ao problema que a imprensa local, politicamente comprometida, procurou não só silenciar as iniciativas levadas a cabo pela outra parte, como, 
no final, tentou "colher os louros" pelos benefícios conseguidos ${ }^{42}$. A 2 de Outubro de 1915, terminados que estavam os trabalhos da Comissão Técnica, afirmava-se na Independência: «O trabalho e os estudos feitos são, pois, obra exclusiva da República. É bom que isto fique registado e do povo conhecido». E a 12 de Fevereiro de 1916, referindo-se à forma como o Partido Progressista tratou o problema, acrescenta: «Foi preciso que nós levantássemos um grito veemente de protesto, confiados como estávamos e estamos, em que algum remédio há-de o governo da República encontrar (...). O que eles pretendem é inutilizar os nossos esforços, prejudicando o povo» ${ }^{43}$. Em resposta, num violento artigo, a Soberania critica as tentativas de aproveitamento político do Partido Democrático, congratulando-se pelo empenhamento manifestado pela Direç̧ão dos Serviços Agrícolas do Norte, sem o qual não teria sido possível a um só indivíduo, o Delegado Agrícola de Aveiro, proceder à avaliação dos prejuízos antes de começarem as colheitas. E termina rematando: «O Partido Democrático, que nada fez em prol da causa, vendo que os trabalhos foram coroados de êxito, chegou a pedir que o contrato com as minas fosse assinado na Câmara Municipal. Não conseguindo, tentou obter toda a documentação do relatório para, junto dos proprietários, mostrar que o acordo a esse partido se devia. (...) O povo interessado sabe, porém, a quem deve o benefício alcançado e a seu tempo terá a prova documentada da nulidade dos serviços do partido democrático e da valia daqueles que foram prestados pela comissão dos proprietários lesados» ${ }^{44}$.

A controvérsia política continuará durante mais algum tempo, mas as forças republicanas só readquirirão a liderança da oposição às minas na Primavera de 1917, quando se levanta o problema do incumprimento do contrato por parte da Companhia e se reacende o velho e insolúvel problema da acidez das águas. É da reunião do Senado Municipal, presidido por César Barata, em finais de Abril de 1917, que sairá a célebre Comissão Regional que levará ao novo ministro do Fomento o ressurgimento da questão.

Diga-se, a bem da verdade, que nenhum outro fenómeno da vida local foi objecto de um tão grande e prolongado aproveitamento político, ou serviu de forma tão persistente de arma de arremesso eleitoral, como o do conflito entre os proprietários dos campos de Águeda e as Minas do Vale do Vouga. 


\section{A QUESTÃO LEGAL}

O problema da (in)compatibilidade entre a agricultura e a indústria mineira, sendo, por um lado, uma questão de interesse particular, era também, por outro lado, uma questão de interesse colectivo, pois estava em causa a salvaguarda do "domínio público". Daí que a via legislativa se tivesse assumido como uma das formas privilegiadas de regulação de conflitos, embora nem sempre tivesse conseguido fugir às contradições políticas do regime republicano, cuja tradição clientelar se reflectiria também na longa batalha que opôs os proprietários de Águeda às Minas do Vale do Vouga.

Malogrado que foi o acordo com a Companhia e baldadas as tentativas de se conseguir dos governos democráticos uma solução política definitiva, todas as energias se concentraram, a partir de 1917, o Parlamento da República, numa tentativa de fazer fechar o círculo político de intervenção dos vários órgãos de soberania.

Como já foi referido, um dos princípios clássicos do direito mineiro assentava no princípio segundo o qual a propriedade mineira pertence ao Estado, alienando este o direito de uso e usufruto aos particulares. Na linha da tradição liberal cabia-lhe o poder de se apropriar do subsolo, como forma de garantir a manutenção do interesse e do "domínio público". A exploração era confiada a particulares, nacionais ou estrangeiros, que só podiam proceder ao início dos trabalhos mediante uma concessão que tinha, desde 1850 , carácter perpétuo ${ }^{45}$. A actividade privada era, portanto, uma questão de interesse colectivo. A grande dificuldade estava, no entanto, na harmonização de ambos os interesses, quando se colocava o problema dos prejuízos provocados a terceiros.

Durante muito tempo pretendeu-se disciplinar os prejuízos causados pela exploração pelos princípios da responsabilidade civil. No entanto, atendendo a que a exploração subterrânea é uma «empresa de audácia excepcional e um desafio corajoso às forças da natureza» (Rodrigues Júnior, 1921: 183), corria-se o risco de um grande número de prejuízos serem atribuídos injustamente. Daí que, com o tempo, tenha vindo a afirmar-se o princípio segundo o qual a responsabilidade pelos danos causados deve ser independente da existência ou não de culpa. Foi essa, aliás, a doutrina que inspirou os principais diplomas que tutelaram a exploração mineira ao longo da segunda metade do século XIX, consagrando o princípio da indemnização como o grande mecanismo regulador de conflitos.

O decreto de 30 de Setembro de 1892 - relativo ao aproveitamento das substâncias minerais, regulamentado pelo Decreto-Lei de 5 de Julho de 
$1894^{46}$, manteve os aspectos essenciais da legislação anterior no que diz respeito à questão das indemnizações. Aí são considerados os prejuízos causados pela lavra à propriedade de superfície, mas de forma um tanto vaga e nunca especificamente à propriedade agrícola, sobretudo se se encontrar fora do perímetro da concessão.

O Regulamento de 1894 , no seu Art. $16^{\circ}$, prevê o pagamento de uma indemnização aos proprietários prejudicados pelos trabalhos de pesquisa, mas reduz o seu âmbito de aplicação «aos proprietários vizinhos da área de pesquisa». De igual modo, na área relativa à regulamentação das condições da concessão, prevê o diploma que no respectivo alvará sejam expressas as condições gerais a que deve sujeitar-se o concessionário. São elas, entre outras, a obrigatoriedade de «responder pelos danos e prejuízos que possam resultar a terceiros, da lavra da mina», sobretudo devido ao «aparecimento de águas na mina, sua condução para fora ou sua encorporação em rios, arroios ou desaguadouros, quando se prove que elas são nocivas». Uma novidade, em relação ao diploma de 1892, é o facto de o concessionário ser obrigado a «executar todos os trabalhos que, pelo governo, lhe sejam determinados para evitar, na medida do possível, os danos que as águas da mina possam causar» ${ }^{47}$. Assim, ainda que um pouco vagos, os instrumentos para intervir existiam e, no caso das minas aqui estudadas, eles foram invocados quando necessário. Se nos lembrarmos do acordado entre os proprietários e a empresa concessionária, na sequência das conclusões dos trabalhos da Comissão Técnica, em 1915, constatamos que a assunção dos prejuízos por parte da empresa resultou no pagamento das indemnizações. A ruptura com as minas aconteceu, devido ao alegado incumprimento dos trabalhos acordados com vista à neutralização das águas, um assunto cujos contornos estavam previstos no acordo, mas não regulamentados na lei. Se, ao mesmo tempo, atentarmos nas penalizações previstas pelo não cumprimento das disposições legais, bem como na flexibilidade existente na aplicação de muitos dos seus aspectos, compreendemos como, muitas vezes, aos povos não restava outra via senão a da violência.

Relativamente a penalizações, são previstas duas situações: a multa e a perda do direito à concessão ${ }^{48}$. Quanto às multas, prevê-se a sua aplicação perante o não cumprimento do clausulado constante do alvará de concessão, mas prevê-se, igualmente, a perda do direito à concessão, em situações excepcionais. São elas, a título de exemplo, a não apresentação do plano de lavra, a inexistência de director técnico, a prática de lavra ambiciosa, a falta de pagamento do imposto dois anos consecutivos, a inactividade da lavra, etc. A aplicação da pena de perda do direito à concessão, sem dúvida a mais radical, mereceu sempre uma imensa resistência da parte do Estado, não só porque retirar uma concessão a alguém podia ser considerado uma 
expropriação, como também porque essa medida levava a uma diminuição das receitas. Daí que o Estado, revelando uma maior preocupação com o interesse públic o, tenha reservado essa prerrogativa, quase exclusivamente, para quando os concessionários deixassem de pagar os devidos impostos (Guimarães, 1994: 51-52). A única situação, em que é admitida a perda de concessão por razões que se prendem com os prejuízos causados a terceiros, está prevista no $\mathrm{n}^{\circ} 5$ do $\operatorname{Art}^{\circ} 52^{\circ}$ e refere-se à falta de pagamento de duas multas consecutivas e à reincidência, pela terceira vez, na contravenção de qualquer das cláusulas com que lhe foi concedida a mina. Como vemos, é de tal forma ténue a preocupação revelada pelos prejuízos causados pelas minas, facto ainda agravado pelo longo contencioso administrativo inerente ao processo, que muito dificilmente esse problema levaria à perda de uma concessão.

A lei 677 de 13 de Abril de $1917^{49}$ mantém, grosso modo, os princípios da legislação anterior, embora clarifique alguns aspectos ligados ao problema dos prejuízos da actividade mineira e, teoricamente, torne mais fácil a aplicação da pena de perda de concessão. No que concerne às condições gerais a que deve satisfazer o concessionário, no que à questão aqui tratada diz respeito, todo o teor do clausulado se mantém inalterável, sendo, no entanto, acrescentado um aspecto importante. Passa a ser expressamente obrigatória a execução das «obras necessárias para evitar o extravio das águas das regas e os inconvenientes e prejuízos resultantes da incorporação das águas de minas em rios, arroios ou desaguadouros quando se prove que elas são nocivas, no prazo que lhe for marcado ${ }^{50}$. De igual modo, no plano das penalidades a aplicar e embora se mantenha a mesma matriz de penas, é introduzida uma novidade. Ao contrário da situação anterior, em que a perda de direito à concessão exigia a acumulação da falta de pagamento de duas multas com a tripla contravenção das cláusulas inscritas no alvará, agora, de acordo com o Art. $100^{\circ}, \S$ único, «pela terceira infracção perderá imediatamente os seus direitos à concessão».

Ainda que no plano teórico, a introdução deste clausulado representava um avanço significativo na clarificação das responsabilidades a assumir pelos prejuízos causados. A própria imprensa democrática local fez eco da aprovação da lei e, regozijando-se pela introdução destas cláusulas, atribuiu-as ao trabalho desenvolvido por Elísio Sucena no Parlamento. É um facto que, desde a sua eleição em 1915, a questão da perda da concessão por motivo de prejuízos a terceiros fora sempre uma das principais preocupações daquele deputado. E, de facto, após falhanço do Poder Executivo, era a grande oportunidade de intervenção pela via legislativa.

A 9 de Julho de 1917, os deputados eleitos pelo distrito de Aveiro, João Elísio Sucena, democrático, Moura Pinto, unionista, e Mesquita Carvalho, 
evolucionista, acordaram na elaboração de um outro projecto de lei que procurava substituir o processo ordinário por perdas e danos, previsto na legislação existente, por um processo especial de indemnizações mais simples e expedito. Ao mesmo tempo, tentava estabelecer um regime de caução por parte dos concessionários de minas, para prejuízos prováveis que as águas pudessem vir a causar. Assim, previa o projecto, no seu Art. $1^{\circ}$, que os concessionários fossem obrigados a «prestar caução aos prejuízos prováveis que poderão causar à agricultura os trabalhos de lavra (...) e de águas nocivas provenientes das entulheiras ou do tratamento do minério» ${ }^{51}$. Sempre que houvesse reclamações, o ministro do Fomento deveria mandar proceder à avaliação dos prejuízos a uma comissão de três peritos, sendo um nomeado pelo concessionário, outro pela Câmara Municipal e o terceiro pelo ministro. Quanto à metodologia a adoptar na avaliação dos prejuízos, seguia-se de perto aquela que foi utilizada pela Comissão Técnica de 1915, estabelecendo a diferença aproximada entre a produção no tempo dos prejuízos e a média dos anos anteriores. Terminada a avaliação, seria o concessionário intimado para, no prazo de 30 dias, entrar com a importância dos prejuízos na tesouraria da Câmara Municipal.

Em finais de Julho, o projecto de lei já tinha baixado à Comissão Parlamentar de Minas. No entanto, para grande indignação das hostes republicanas locais, as Câmaras acabariam por fechar sem que o projecto de lei fosse discutido e aprovado. Gorava-se, assim, a última tentativa para, pela via política e institucional, provar ao Concelho que as instituições republicanas eram capazes de solucionar, a contento de Águeda, o problema das minas. A 25 de Agosto de 1917, era a própria imprensa republicana que criticava violentamente a classe política por, «em vez de animar o povo e lhe dar o que ele necessita, nada mais (fazer) do que lançar ondas de desalento e de vergonha» ${ }^{52}$.

O consulado sidonista traria importantes alterações no xadrez político local, dando ao sector monárquico-conservador, liderado pelo conde de Águeda, um protagonismo político que jamais tivera desde o 5 de Outubro. Logo nos primeiros meses de 1918, o Conde desenvolve uma discreta campanha junto do governo, fazendo accionar o clientelismo político da área do poder, agora favorável ao sector monárquico. Nas eleições de 28 de Abril de 1918, Águeda elegeria dois destacados representantes seus nos círculos políticos lisboetas. Para o Senado, o conde de Águeda e, para a Câmara de Deputados, José de Sucena, filho do influente Conde de Sucena.

O conde de Águeda que, em Lisboa, ainda se movimentava facilmente nos corredores do poder, consegue a publicação de um decreto que, com pequenas alterações, corresponde ao projecto de lei apresentado, um ano antes, pelos deputados eleitos pelo círculo distrital de Aveiro. Mais uma vez, 
a questão das minas funcionava como uma oportuna arma de arremesso político e como um importante trunfo a jogar na cartada eleitoral. Tudo fora calculado ao pormenor. A campanha eleitoral encontrava-se ao rubro, dando a Soberania do Povo, durante toda a semana, um grande destaque ao assunto. A 20 de Abril realizou-se uma imponente manifestação de apoio ao conde de Águeda, quando este regressava de Lisboa $^{53}$, que se transformou num autêntico comício.

Publicado a 26 de Abril, o novo decreto ${ }^{54}$ suprime o artigo $1^{\circ}$ do projecto anterior, que pressupunha o depósito de uma caução por parte do concessionário, mantendo toda a restante estrutura. De acordo com o diploma, sempre que forem apresentadas ao governo reclamações de agricultores por prejuízo causado pela lavra de minas, mandará o Ministério do Trabalho, pela respectiva circunscrição mineira, proceder à comprovação dos factos $\left(\operatorname{art.~} 1^{\circ}\right)$. Uma vez provados, cabe ao Ministério da Agricultura, recentemente criado, proceder à avaliação dos danos. De referir que, por este decreto, a Câmara Municipal volta a assumir a liderança do processo como representante dos agricultores prejudicados $\left(\operatorname{art} 1^{\circ}\right)$. A ela cabe nomear um dos três peritos que integrarão a comissão ${ }^{55} \mathrm{e}$, terminada a avaliação, volta a ser ela a fiel depositária da indemnização paga pelos concessionários ou empresa concessionária (art. $3^{\circ}$ ). Relativamente a penalizações, mantêm-se as que estão previstas na legislação anterior, sendo a multa, para o não cumprimento do artigo $3^{\circ}$, imposta pelo juiz da comarca e de montante igual ao valor dos prejuízos. No caso de a multa não ser paga no prazo estabelecido, volta a Câmara a ser a entidade competente para requerer o pagamento em processo de execução (art. $7^{\circ}$ ). Prevê o decreto a perda da concessão, ficando no entanto limitada à ocorrência de duas situações cumulativas: a aplicação da multa por não pagamento da indemnização e, também, a não execução, dentro dos prazos fixados, dos trabalhos necessários à correcção dos prejuízos causados à agricultura (art. $10^{\circ}$ ). A perda de concessão como penalização por prejuízos causados continuava, assim, uma medida distante e de exequibilidade difícil, pois dependia de um longo processo burocrático.

Ambos os jornais locais publicaram o referido diploma legal. A Independência evidencia, como se esperava, a semelhança com o projecto de lei anterior, embora critique o desaparecimento da caução obrigatória, uma vez que poderia reverter «a favor dos lavradores, caso as empresas mineiras não entrassem com a importância dos prejuízos avaliados» ${ }^{56}$. Critica também o facto de, ao contrário do projecto anterior, em que a avaliação tinha lugar logo após a reclamação, ser agora necessário comprovar primeiro os factos constantes da queixa. E acrescenta: «O público compreende... A 
circunscrição mineira a comprovar... Santo Deus! Parece que isso nunca chegará a acontecer».

A Soberania contesta esta posição alegando que, não havendo sido a exigência da caução consignada em lei anterior ao respectivo alvará de concessão, este não podia agora ser modificado. E por outro lado, como muitas empresas mineiras pertencem a estrangeiros, essa cláusula levaria com certeza a reclamações diplomáticas. Esquecia-se a Soberania que a lei de 13 Abril de 1917 também impusera às empresas mineiras algumas condições que não constavam da legislação anterior e, portanto, dos respectivos alvarás de concessão. Entre elas, a obrigatoriedade de as empresas concessionárias procederem aos trabalhos necessários para evitar os prejuízos das águas das minas, quando incorporadas em rios. Foi aplicando essa cláusula que o ministro Herculano Galhardo, na sequência dos acontecimentos de Maio de 1917, em Águeda, intimou a Companhia das minas a proceder à execução de algumas obras, por forma a melhorar o processo de neutralização em curso.

O combate político em torno da questão das minas prossegue ao longo do ano de 1918, ganhando novo alento com a publicação do decreto de 19 de Junho que vinha, assim, regulamentar o de 26 de Abril. Estabeleceu o princípio da indemnização, mas não regulou a forma de o executar ${ }^{57}$.

Segundo o regulamento então publicado, em parte dirigido às "Minas das Talhadas", os proprietários prejudicados deverão entregar na Câmara Municipal uma petição onde se refira a natureza, extensão e valor provável dos prejuízos sofridos no ano anterior (art. $1^{\circ}$ ). O chefe da circunscrição mineira respectiva deverá visitar a mina ou os locais que se dizem prejudicados, visita que deverá ser acompanhada pelo presidente da Câmara ou seu representante e pelo concessionário ou seu representante (art. $1^{\circ} \S 3$ ). Após reunião realizada entre as partes, e caso não se chegue a um acordo, o caso é enviado ao juiz da comarca que nomeará os peritos que irão proceder à avaliação dos prejuízos. Depois de concluídos os trabalhos e verificadas todas as formalidades legais, o presidente da Câmara Municipal, que representará os agricultores reclamantes, intimará o concessionário a entregar na respectiva tesouraria o valor total fixado para fazer face aos prejuízos (art. $\left.11^{\circ}\right) . \mathrm{E}$ agora, referindo-se directamente ao caso de Águeda, o art. $14^{\circ}$ considera já «devidamente comprovada a responsabilidade das minas nos prejuízos sofridos até 31 de Dezembro de 1917, pelas propriedades abrangidas na área estudada pela comissão técnica» de $1915^{58}$, devendo os proprietários abrangidos apresentar as suas petições. Acrescenta ainda o artigo, no seu $\S 3$, que se algum proprietário tiver já recebido do concessionário das minas indemnização total não terá direito a nova 
indemnização. Se tiver recebido indemnização parcial receberá apenas a diferença entre a indemnização recebida e o valor do prejuízo.

Relativamente a penalizações, o decreto continuava a prever a multa para o não pagamento do valor fixado aos prejuízos. No entanto, reduzia o seu montante a $20 \%$ do total da indemnização. A perda da concessão reserva-se, agora, apenas ao incumprimento dos prazos na execução das obras.

Apesar do edifício legal produzido e reproduzido, o problema da inquinação das águas dos rios e da infertilidade dos solos do vale do Águeda continua, e continuará por muito tempo, a alimentar os ódios do povo contra a Companhia das Minas do Vale do Vouga e contra o seu odiado director técnico, Pedro Amôr Monteiro de Barros. Apesar de decretado e regulamentado, o princípio da indemnização continuava a não responder ao problema fundamental: o ódio popular contra as minas.

Não obstante a expectativa de normalização criada pela mais recente produção legislativa e pela esperança de um futuro melhor alimentada pelo fim da Guerra, os anos que se seguem ficarão marcados pela conjugação de dois importantes e curiosos fenómenos: por um lado, o comportamento das autoridades municipais e judiciais que, após o período conturbado da Monarquia do Norte, registaram uma inexplicável inércia no cumprimento das suas atribuições na condução do processo; por outro lado, a acção do poderosíssimo lobby das Minas, num período de grande instabilidade política como foi o dos anos de 1920 a 22. Essa acção levaria à criação do decreto 8371, de 25 de Agosto de $1922^{59}$, que, revogando a legislação anterior em matéria de indemnização de prejuízos e deitando por terra o derradeiro esforço das clientelas políticas locais, esgotava definitivamente a crença na possibilidade de uma solução legal e política para o problema. Ficou conhecido, em Águeda, como o "Decreto Ladrão" e esteve na base de uma longa e contraditória batalha jurídico-política, cuja revogação coincidiria com a chamada "noite mais longa de Águeda". Na madrugada de 28 de Junho de 1924, um grupo de populares, dirigido por um autodenominado "Comité de assalto", deslocou-se às minas, destruiu a turbina e a lavaria e lançou fogo à casa de habitação do director. 


\section{CONCLUSÃO: A "NOITE MAIS LONGA DE ÁGUEDA"}

A publicação do decreto 8371, de 25 de Agosto de 1922, vinha demonstrar, de facto, que o fim do sidonismo trouxera consigo uma importante alteração na correlação de forças entre os interesses mineiros e o lobby constituído pelos proprietários de locais, liderados pelo Conde de Águeda. O processo de reavaliação dos prejuízos, movido pelos proprietários logo após a publicação dos diplomas 4159 e 4544, de 26 de Abril e 19 de Junho de 1918, arrastar-se-ia na Comarca de Águeda ao longo de quatro anos, em consequência dos sucessivos expedientes legais de que se socorreram os peritos nomeados pela companhia concessionária. $\mathrm{O}$ comportamento permissivo das autoridades judiciais, bem como a própria inércia da Câmara Municipal no desempenho das obrigações que lhe estavam cometidas, como representante legal dos proprietários, fariam levantar todo o tipo de suspeições em relação à influência exercida pela companhia junto das mais altas esferas do poder. O seu principal objectivo era o de atrasar, tanto quanto possível, o processo, de modo a que outro diploma, mais consentâneo com os seus interesses, pudesse ver a luz do dia. E, na realidade, o novo decreto não só tornava mais difícil e moroso o apuramento das responsabilidades dos concessionários em matéria de prejuízos, como, também, permitia à Companhia das Minas do Vale do Vouga requerer novas vistorias e novas avaliações, fazendo eternizar o problema do pagamento das indemnizações devidas.

Durante a fase final do ano de 1922 e todo o ano de 1923 assistiu-se a um interessante debate público que, transcendendo o âmbito geográfico do Concelho, se centrou no problema da coexistência entre a indústria mineira $\mathrm{e}$ a actividade agrícola, dois sectores de interesse estratégico para a economia portuguesa. O Congresso Agrícola de Viseu, reunido a 8 de Junho de 1923, aprovara uma moção que defendia a modificação da legislação mineira, por forma a que, nas explorações em actividade e nas concessões futuras, fossem defendidos os interesses da área agrícola do País. O jornal Soberania do Povo ${ }^{60}$ transcreve mesmo um interessante artigo da Gazeta das Aldeias, da autoria de Júlio de Mello e Mattos, onde é questionada a própria gestão do subsolo nacional ${ }^{61}$ : «Exportam-se as matérias-primas [afirma-se], deixando esgotados os jazigos com insignificante remuneração para o Estado e pequena distribuição de jornais a operários portugueses (...). Os grandes lucros da transformação ficam nas empresas estrangeiras em geral, exploradoras dos jazigos ou associadas às que obtém as concessões (...). As empresas concessionárias lançam a garra à terra que não é deles, fazem o simulacro de indemnização lançando aos espoliados uns parcos escudos, mas ai daqueles que estão a jusante, porque as águas esterilizantes queimam-lhes 
as culturas e deterioram-lhes para sempre os campos marginais... e sem indemnização alguma (...). A legislação permite-o, o estrangeiro explorador encheu as algibeiras, o proprietário arruinou-se».

Em finais de Janeiro de 1924, começa a circular, em Águeda, um manifesto, assinado por personalidades de todos os quadrantes políticos, convocando um comício para o dia 3 de Fevereiro (anexo III). Procurava mostrar-se ao País que, ao contrário do que se ia sugerindo em alguma imprensa de Lisboa, monárquicos e republicanos estavam unidos nesta causa comum $^{62}$. Ao mesmo tempo, tentava obter-se a necessária legitimação popular para o esforço desenvolvido por algumas personalidades, em particular Afonso de Melo e Manuel Alegre, no sentido de se conseguir a revogação do chamado "Decreto Ladrão". Considerado por muitos o "primeiro grito de guerra contra as minas", o comício foi presenciado por uma enorme multidão e decorreu sob um clima de grande unanimidade de pontos de vista. Aquele periódico refere mesmo que a nota predominante do comício foi a «descrença do povo nos remédios ordinários» e a «crença única nos remédios heróicos». Entre a multidão, era possível ouvirem-se vozes exaltadas vociferando: "vamos lá acima!", "vamos às minas!", «arrasemos aquilo tudo!» ${ }^{63}$.

Desta importante reunião magna, terão saído duas ideias-força: em primeiro lugar, o apoio incondicional à revogação do odiado diploma de 1922, revogação essa que o então ministro do Trabalho, Pedro Pita, havia assinado em Dezembro, antes de abandonar o cargo, mas cuja publicação o lobby mineiro conseguira protelar; em segundo lugar, solicitar, junto do Governo, o encerramento das minas, até que fossem realizadas as obras de neutralização das águas.

Decorreram os meses subsequentes sem que qualquer medida concreta fosse tomada. Nos primeiros dias do mês de Junho as águas vieram, de novo, bastante esverdeadas, queixando-se as lavadeiras de que as roupas ficavam da cor do sulfato. Na madrugada de 28 de Junho, uma multidão munida de paus, espingardas e roçadeiras, respondendo ao toque a rebate dos sinos das freguesias ribeirinhas, concentrou-se na Praça Nova da vila e, «em camiões, camionetas, automóveis e em carros», ou mesmo a pé, dirigiu-se para as Talhadas a fim de assaltar as minas. O jornal Soberania do Povo, nesse mesmo dia, ainda "a quente", afirma tratar-se de uma «Guerra Santa», mas «em legítima defesa». Estávamos perante «uma multidão formada de intrépidas pessoas de todas as classes sociais (...), cujos rostos, o ódio às minas malditas e a febre do entusiasmo pelo combate de extermínio contra quem cobardemente lhe rouba o pão, transfiguravam a ponto de os tornarem inteiramente desconhecidos». A turbina, a lavaria e as restantes instalações pertencentes ao complexo mineiro foram dinamitadas e incendiadas. No dia 
seguinte, chegava Águeda o Diário do Governo, em cujo número vinha já o decreto de Pedro Pita que, dois dias antes, o ministro do Trabalho, Lima Duque, mandara publicar.

Por dificuldades de comunicação, ou talvez não, a notícia chegara tarde demais. Os povos, saturadas das contradições do sistema político, haviam feito justiça pelas suas próprias mãos. 


\section{NOTAS}

* O presente artigo resulta do trabalho realizado, sobre a mesma temática, sob a orientação do Professor Doutor José M. Amado Mendes, no âmbito do Seminário "Industrialização e Património Industrial" do Curso de Mestrado de História Económica e Social Contemporânea, a decorrer na Faculdade de Letras da Universidade de Coimbra, entre 1998-2000.

${ }^{1}$ De todas, apenas a concessões do "Cabeço da Macieira" e do "Vale do Bicho" foram objecto de exploração intensiva. Trata-se das concessões mais antigas, com alvará de 1889 e 1892, respectivamente. As restantes, obtiveram alvará de concessão, a saber: "Avide" e Vilarinho, em 1913, e "Lomba da Fonte da Serra", "Porto de Vilarinho" e "Vale do Vau", em 1922 (Instituto Geológico e Mineiro, processo de minas abandonadas, $\mathrm{n}^{\circ}$ 227). Doravante designá-lo-emos por IGM, 227.

2 A concessão do "Cabeço da Macieira" teve como descobridor legal Manuel Francisco Ladeira, residente na Freguesia de Talhadas, Concelho de Sever do Vouga, que constituiu uma sociedade, em 1885, denominada Sociedade exploradora das minas do Cabeço da Macieira. A concessão passaria, em 16 de Janeiro de 1909, para a posse da sociedade comercial por quotas Minas do Vale do Vouga, Limitada, cujo principal accionista era o banqueiro portuense Joaquim Pinto da Fonseca, que viria a adquirir, em 1913, a concessão do "Vale do Bicho" (IGM, 227; 246).

3 A mina de cobre do "Vale do Bicho" teve como descobridora legal a sociedade constituída, em 12 de Março de 1889, pela firma comercial Ferreira \& C. ${ }^{\text {a }}$, o alemão Wilhelm Shad e João José Ventura, sediada em Albergaria-a-Velha, tendo passado mais tarde para a posse de Manuel Luís Ferreira e sua mulher, também residentes naquela vila (IGM, 246).

${ }^{4}$ IGM, 227

${ }^{5}$ Trata-se de Benjamim Camossa, um abastado comerciante local, falecido em 1909 e que, durante anos, esteve ligado aos executivos camarários do Partido Progressista.

${ }^{6}$ Actas das Sessões da Câmara Municipal de Águeda, sessão de 18 de Maio de 1911 e seguintes.

${ }^{7}$ Tratava-se de um «grande carro que causou a admiração de todos quantos o viram, por se parecer com as máquinas dos comboios do Vale do Vouga» (Soberania do Povo, 17/2/1912).

${ }^{8}$ Inaugurado a 8 de Setembro de 1911.

${ }^{9}$ Relatório dos Trabalhos da Comissão Técnica, nomeada para estudar os efeitos das águas das Minas do Vale do Vouga nas culturas dos campos marginais do Águeda e do Alfusqueiro em 1915, as causas dos prejuízos verificados e sua avaliação, Coimbra, Imprensa da Universidade, 1916.

10 «A Câmara reconhece as vantagens deste melhoramento que muito beneficiará a região confinante e os povos circunvizinhos» ("Actas das sessões da Comissão Executiva da Câmara Municipal de Águeda”, 29/10/1909).

${ }^{11}$ Soberania do Povo, 10 de Março de 1915.

${ }^{12}$ Independência de Águeda, 24 de Julho de 1915.

13 Tratava-se da tentativa de adaptar à questão dos prejuízos o que se encontrava já preceituado na legislação em vigor (Dec. de 30 de Setembro de 1892, regulamentado a 5 de Julho de 1894).

${ }^{14}$ Soberania [...], 28 de Julho de 1915

${ }^{15} \mathrm{Um}$ desses relatórios, da autoria de Alfredo Bensaúde, embora não negando o estado dos campos, procurava desresponsabilizar esta empresa. No entanto, não respondia, segundo os meios ligados ao conflito, a uma questão essencial, a saber: estando ali os entulhos há tantos anos, porque é que só agora se começara a notar um aumento 
desmesurado da esterilização dos campos? (Independência [...], 28 de Agosto e 18 de Setembro de 1915; IGM, 227; Diário do Governo, II série, nº 192 de 20/8/15).

16 A caracterização deste tipo de exploração agrícola ficava, assim, clara: «O proprietário colhe das suas terras o milho e o feijão, com que sustenta a família; o milharal é semeado basto de propósito para que com o milho do desbaste possa prover à alimentação de uma junta de bois e o milharal é em tais condições um prado monofito; colhido o milho, vejeta no mesmo terreno o azevém à arrenda do cereal, e assim continua a alimentar o seu gado; a terra que produziu o milho é agora um prado de azevém; a bandeira e a palha do milho são auxiliares valiosos da alimentação do gado bovino (...)! Há uma indústria subsidiária, donde os agricultores tiram o pouco de que necessitam para completar a sua alimentação e adquirir o seu vestuário. Essa indústria é constituída pela compra e venda sucessiva do gado bovino, que eles recriam engordam e, se não fora essa indústria, auxiliar da precária e pouco lucrativa cultura do milho, o proprietário não poderia viver» (Relatório dos Trabalhos da Comissão Técnica, nomeada para estudar os efeitos das águas das minas do Vale do Vouga nas culturas dos campos marginais do Águeda e do Alfusqueiro em 1915, as causas dos prejuizos verificados e sua avaliação, Coimbra, Imprensa da Universidade, 1916).

17 Relatório dos Trabalhos da Comissão Técnica [...], Coimbra, Imprensa da Universidade, 1916.

${ }^{18}$ Os campos atingidos estendiam-se desde «a margem esquerda do rio Vouga e Ponte da Rata ao NW., até à Ponte de Bolfiar a E., abrangendo todo o percurso do Águeda e continuando daí no mesmo rumo até ao Regato dos Moinhos, adjacentes ás duas margens do Alfusqueiro. São, pois, cortados, no sentido do seu maior comprimento, que regula por 16 a 18 quilómetros, pelos rios Águeda e Alfusqueiro; são separados do concelho de Aveiro e do de Oliveira do Bairro a S. e SW. Pela margem esquerda do Águeda, margem direita do rio Certoma e pela Pateira de Fermentelos, lagoa formada por este último rio, afluente do Águeda, tendo a sua foz à Ponte de Requeixo; dí até ao extremo são limitados na margem esquerda (S.) pelas aldeias de Ois da Ribeira, Espinhel, Recardães, Sardão, Borralha e Bolfiar; e na margem direita (N.) pelas de Travassô, Cabanões, Casal de Álvaro, Oronhe, Casaínho de Baixo e de Cima, Paredes, vila de Águeda e aldeias de Assequins e Raivo». No cômputo geral foram visitadas 888 propriedades (Mapa anexo I).

19 Trata-se de um processo de precipitação do cobre contido na água, através da colocação nos tanques de pranchas de ferro, ou sucatas, que eram consumidas pela acção dos ácidos. Afirma o relator que apenas assistiu a dois ensaios de "cementação" que apenas resultaram em parte, dada a velocidade a que, por via do declive do terreno, as águas passavam sobre as chapas de sucata.

20 «1 ${ }^{\circ}$ Que os terrenos dos campos de Águeda estão muito empobrecidos nos elementos úteis à vegetação e assim esterilizados, pela acção do ácido sulfúrico, dos sulfatos e dos cloretos; $2^{\circ}$ Que é necessário corrigi-los, para que voltem ao grau anterior da sua notável fertilidade, aplicando a cal, a cinza de lenha e fortes adubações; $3^{\circ}$ Que a quantidade de cal a distribuir por cada hectare, durante três anos, pelo menos não deve ser inferior a 500 quilos, a de cinza a 1000 quilos e o estrume do curral a 60 carradas regulares; $4^{\circ}$ Que deve ser preferida para esse fim a cal, há mais tempo derregada, distribuindo metade, um mês antes da lavra, se for possível, e a restante sobre a leiva, juntamente com os mil quilos de cinza; $5^{\circ}$ Que deve preferir-se à cultura do milho branco, de cana alta, que há muitos anos se cultiva nos campos de Águeda, a do milho verdeal, que esta Comissão verificou ser mais resistente; $6^{\circ}$ Que a esterilização dos campos de Águeda, bem como o desaparecimento do peixe nos rios Alfusqueiro e Águeda, são devidos à inquinação das águas dos mesmos rios pelas águas das minas do Vale do Vouga, nas Talhadas; $7^{\circ}$ Que a actual Empresa Exploradora das referidas minas é responsável, nos termos do Regulamento de 5 de Julho de 1894 e Alvarás de 22 de Março 288 
de 1889, 6 de Agosto de 1892 e 25 de Setembro de 1909, por todos os prejuízos causados nos campos e rios a que se refere a conclusão anterior; $8^{\circ}$ Que a mesma Empresa deve pagar todos os prejuízos avaliados por esta Comissão e sanear, sem demora, as águas, entulhos e lamas das minas, ficando responsável pelos prejuízos futuro, até que desapareça o efeito da inquinação das águas; $9^{\circ}$ Que, finalmente, a Empresa deve fornecer aos proprietários os correctivos indispensáveis, para saneamento dos terrenos esterilizados, até que eles entrem em produção regular» (Relatório [...], p. 23 e 24).

${ }^{21}$ Constituída a 12 de Junho de 1916, a nova sociedade contava com os seguintes accionistas: a anterior concessionária, a sociedade por quotas Minas do Vale do Vouga, Limitada; Louis Rochet, Albert Louis Marie Michaut, Joaquim Pinto da Fonseca, Manuel Pinto da Fonseca, Joaquim Pinto da Fonseca Junior, Miguel de Sousa Guedes Machado, Custódio Pereira, Eduardo Alves Ferreira Cardoso, Victorino Nogueira Gonçalves e Joaquim de Carvalho Pinto Basto. O Capital Social era de 200 contos, divididos em 4 mil acções de 50\$00, distribuídas da seguinte forma: 195 contos foram subscritos pela anterior sociedade e os restantes 5 contos subscritos em partes iguais pelos restantes dez accionistas (Estatutos da Companhia das Minas do Vale do Vouga, Porto, 1916, IGM, Pasta de escrituras públicas de companhias de minas desactivadas).

${ }^{22}$ Em ofício enviado ao Ministério das Finanças, em Março de 1917, na sequência do indeferimento da reclamação colectiva que solicitava a anulação da contribuição predial, o presidente da Comissão Executiva da Câmara Municipal, Celestino Neto, num veemente protesto, refere que a quebra na produção é de $50 \%$ em relação ao ano de 1915 . Este ofício marca o início de uma nova fase de contestação, numa altura em que é já muito evidente a correlação entre a crise das subsistências e o agravamento da conjuntura económica local (Independência [...], 24 de Março de 1917).

${ }^{23}$ A 7 de Julho de 1917 afirmava-se no jornal Independência de Águeda: «Vai um sentimento de descrença pela eficácia das medidas do Governo (...). Há um velho princípio do direito que manda prevalecer o bem colectivo em detrimento dos benefícios particulares. É um princípio que está na legislação de todos os povos».

${ }^{24}$ Soberania [...], 23 de Maio de 1917. Na queixa enviada ao Delegado do Procurador da República de Águeda, o engenheiro director técnico das minas, Pedro Amôr Monteiro de Barros, refere que um total de 150 barricas de minério e 300 carris de aço terão sido lançados ao rio (IGM, 227).

${ }^{25}$ Delegação Regional do Centro do Ministério da Economia, fundo do Serviço de Fomento Mineiro, minas abandonadas, processo $\mathrm{n}^{\circ} 227$.

${ }^{26}$ Louis Rochet, director técnico e accionista da Companhia, sempre fora respeitado nos meios ligados à contestação, sendo considerado o principal interlocutor e a figura mais empenhada na solução do problema. Seria substituído por Pedro Amôr Monteiro de Barros, licenciado em Engenharia de Minas pelo Instituto Superior Técnico do Porto. A entrada do novo director técnico não deixa de ser interessante, se tivermos em conta que a admissão de engenheiros portugueses na actividade industrial, particularmente na indústria mineira, não era prática corrente no princípio do século, mesmo entre as companhias portuguesas. Essa exigência viria a ser imposta, pouco depois, pela via legislativa (Guimarães, 1994: 47).

${ }^{27}$ Não cabe no âmbito deste trabalho a caracterização exaustiva e circunstanciada da realidade política local. No entanto, sabemos que as clivagens existentes dentro do Partido Republicano, consubstanciadas em duas perspectivas diferentes relativamente à consolidação do regime, cedo se começaram a manifestar em Águeda. Um republicanismo radical, autodenominado herdeiro do velho Partido Republicano e próximo de Afonso Costa, defendia a restrição do acesso à participação política das forças hostis e revia-se no jornal Independência de Águeda, fundado e dirigido por Eugénio Ribeiro; um republicanismo moderado, próximo da sensibilidade de António José de 
Almeida, abria-se à participação política generalizada e à procura da legitimidade nacional e girava em torno do jornal Povo de Águeda e do seu director Abílio Nápoles. Os unionistas de Brito Camacho tinham aqui pouca representatividade. Assim, considerando que o Partido Democrático foi quase sempre hegemónico no Concelho durante o período estudado, optámos por equacionar apenas as duas forças políticas dominantes: o republicanismo radical do Partido Democrático e as forças conservadoras e monárquicas herdeiras do velho Partido Progressista, dirigidas pelo Conde de Águeda e girando em torno do jornal Soberania do Povo.

${ }^{28}$ Nessa reunião o Conde de Águeda proferiu algumas palavras que não escondiam uma clara vontade de adesão ao novo regime. Afirmava então: «A proclamação da República foi um facto dos mais grandiosos que enchem a nossa história (...). O sangue derramado nas ruas de Lisboa foi sangue abençoado, porque veio redimir uma Pátria abatida, uma nação defracada, que debalde queria vitalizar-se e engrandecer-se, mas que as ambições partidárias não deixaram consegui-lo». Aí foi aprovada uma moção que contemplava a adesão do Partido Progressista do Distrito, «leal e desinteressadamente», às novas instituições republicanas. A Comissão Municipal Republicana de Águeda reage a esta proposta, afirmando que não aceita adesões colectivas. Todos os republicanos, que quisessem aderir ao partido e ao regime, teriam de inscrever-se individualmente no cadastro partidário (Soberania do Povo, 12 Outubro e Independência de Águeda, 22 de Outubro de 1910 e ss).

${ }^{29}$ Soberania [...], 31 de Dezembro de 1910.

${ }^{30}$ À praça Conselheiro Albano de Melo e ao largo Conde de Sucena foram atribuídos os nomes de Praça da República e largo 5 de Outubro, respectivamente (Soberania [...], 7 de Janeiro de 1911).

${ }^{31}$ Nascido em Águeda em 19 de Março de 1844, era formado em Direito e manteve a liderança do Partido Progressista do Distrito de Aveiro, desde 1887 até à implantação da República. Em 1887 foi eleito presidente da Câmara Municipal de Águeda e deputado pelo círculo de Aveiro, pelo qual foi reeleito sucessivamente, na oposição, até 1898, ano em que assumiu, pela primeira vez, o cargo de governador civil de Aveiro. Voltaria a ser governador civil entre 1904 e 1906, ano em que assumiu o cargo de director geral da justiça, que exerceu até ser destituído pelo novo regime implantado em 1910. Faleceu a 27 de Fevereiro de 1913. Num artigo publicado no jornal Soberania do Povo, a 17 de Dezembro de 1910, Mateus Pereira Pinto considerou-o «o primeiro cacique (...) da geração actual».

${ }^{32}$ Manuel Alegre, advogado, foi o operacional destacado para a Junta da Carbonária do Centro, responsável pelo distrito de Aveiro, e o presidente da primeira Comissão Republicana local. Era secundado por nomes como: Eugénio Ribeiro, Augusto Reis, Jessé Gomes Soares, José Pires Claro, Fernando Rocha, o pioneiro da indústria metalúrgica em Águeda, Domingos Pinto de Carvalho, António F. Neves, Armando Castela e Joaquim Sousa Brites. Eleito deputado logo nas eleições de Junho de 1911, foi um dos mais influentes políticos locais e um dos homens de confiança do Partido Democrático para o distrito de Aveiro. Era amigo íntimo dos maiores vultos do Partido Republicano Português, como Afonso Costa, António José de Almeida, Brito Camacho, Euzébio Leão, Magalhães Lima, Machado Santos, José Relvas, entre outros. Desempenhou o cargo de Governador Civil de Santarém e foi várias vezes deputado durante os primeiros anos da República. Eugénio Ribeiro, médico, fundador do jornal Independência de Águeda, em 1904, foi durante muito tempo o líder republicano local e o principal elo de ligação entre o partido, Manuel Alegre e as clientelas locais. Desempenhou o cargo de presidente da Comissão Executiva da Câmara Municipal de Águeda, administrador do Concelho e, mais tarde, de governador civil. João Elísio Sucena, advogado, destacado dirigente do Partido Democrático em Águeda, foi eleito várias vezes deputado. 
${ }^{33}$ Soberania [...], 26 de Novembro de 1910

${ }^{34}$ Soberania [...], 17 de Dezembro de 1910

${ }^{35}$ Soberania [...], 7 de Agosto de 1915.

${ }^{36}$ Soberania [...], 6 de Junho de 1917.

${ }^{37}$ Logo em Janeiro de 1911, o problema chega ao conhecimento do ministro do Fomento, Brito Camacho, pelos canais partidários. A 7 de Janeiro, podia ler-se no jornal Independência de Águeda: «o problema foi tratado entre os dirigentes do Partido Republicano e um amigo nosso se encarregou de o entregar pessoalmente ao ministro».

${ }^{38}$ A ditadura de Pimenta de Castro, vigente entre 25 de Janeiro e 14 de Maio de 1915, não provocou grandes sobressaltos políticos a nível local, já que a dissolução da Comissão Municipal ocorreu já em finais de Abril. A principal alteração, com consequências na vida política local, foi a destituição de Eugénio Ribeiro do cargo de Governador Civil, para o qual havia sido nomeado a 30 de Dezembro de 1914. Após a queda do Governo de Pimenta de Castro, e em consequência do quadro político definido com as eleições de Junho de 1915, Eugénio Ribeiro voltaria a assumir essas funções.

${ }^{39}$ Independência [...], 12 de Junho de 1915.

${ }^{40}$ Após os acontecimentos de Maio de 1917 em Águeda, Manuel Alegre, ainda governador civil de Santarém, envia um telegrama a solidarizar-se com o povo, disponibilizando-se para intervir junto de Afonso Costa.

${ }^{41}$ Independência [...], 24 de Julho de 1915.

${ }^{42}$ Para além dos jornais já referidos, também o Povo de Águeda, afecto ao Partido Evolucionista, entrou neste combate. Apesar de usar de uma certa contenção em questões de política geral, pois estávamos em pleno consulado "União Sagrada", não se coibiu de, a partir de Junho, atacar violentamente o Partido Democrático, pela sua postura em relação à questão das minas.

${ }^{43}$ Ver ainda Independência [...], 8 de Abril de 1916, onde se afirma: «(...)e a República, mal desembainha a espada, mal os ecos dos canhões adormeceram no último recanto da serra, logo desfraldou a bandeira das justas reivindicações da nossa terra, para pedir o saneamento das águas que as minas do Vale do Vouga haviam inquinado». E a 20 de Maio: «Mais uma vez, pois, o novo regime olhou com desvelo para o povo, e este, certamente agradecido, não deixará de dizer bem alto: - Viva a República!».

${ }^{44}$ Soberania [...], 28 de Maio de 1916.

${ }^{45}$ Lei de 25 de Julho de 1850, substituída pela de 31 de Dezembro de 1852 e regulamentada pelo decreto de 9 de Dezembro de 1853. A perpetuidade foi uma das formas de assegurar a lavra, uma vez que era uma actividade que exigia o investimento de enormes capitais.

${ }^{46} D G \mathrm{n}^{\circ} 225$, de 5 de Outubro e $\mathrm{n}^{\circ} 181$ de 13 de Agosto, respectivamente.

${ }^{47}$ Regulamento de 1894 , Art. $36^{\circ}, 2^{\circ}, 3^{\circ}$ e $5^{\circ}$.

${ }^{48}$ Artigos $51^{\circ}$ a $55^{\circ}$.

${ }^{49} D G \mathrm{n}^{\mathrm{o}} 57$ I série, de 13 de Abril.

${ }^{50}$ Art. $51, \mathrm{n}^{\circ}$ 14. A exigência de comprovação aplicava-se claramente às Minas das Talhadas, pois as conclusões do relatório de 1915 não deixavam quaisquer dúvidas quanto à sua responsabilidade na situação em que se encontravam os campos de Águeda. No entanto, a questão da prova, para além de complexa, resultava num processo lento e moroso. O sublinhado é nosso.

${ }^{51}$ Independência [...], 14 de Julho de 1917.

52 Aqui se explicará, mais tarde, que o projecto não foi aprovado porque dos 20 projectos e propostas existentes, este foi colocado em terceiro lugar, logo atrás da questão do empréstimo a Angola e da reforma do contrato com a Empresa das Águas de Lisboa, tendo a oposição demorado propositadamente muito tempo na discussão da primeira, pois 
a resolução da segunda significava o fim da greve que então decorria (Independência [...], 11de Maio de 1918).

${ }^{53}$ Soberania [...], 20 e 24 de Abril de 1918. O aproveitamento político da questão foi levado ao extremo, tendo corrido mesmo o boato de que o Conde havia conseguido o encerramento dos trabalhos da mina.

${ }^{54}$ Decreto $\mathrm{n}^{\circ} 4159, D G \mathrm{n}^{\circ}$ 89, de 26 de Abril de 1918.

${ }^{55}$ Os outros dois eram nomeados, um pelo concessionário e o outro pelo Ministério da Agricultura.

${ }^{56}$ Independência [...], 4 de Maio de 1918.

${ }^{57}$ Decreto 4544, $D G$ n ${ }^{\circ} 148$, de 19 de Junho de 1918.

${ }^{58}$ Nos termos a que referia o parecer da circunscrição mineira publicado no $D G$ $\mathrm{n}^{\circ} 192,2^{\text {a }}$ Serie, de 20 de Agosto de 1915.

${ }^{59} D G$ n 192 , de 15 de Setembro de 1922.

${ }^{60}$ Soberania [....], 6 de Outubro de 1923.

${ }^{61}$ Gazeta das Aldeias, 28 de Setembro de 1923.

${ }^{62}$ No início do mês de Janeiro de 1924, eram publicados no Jornal $O$ Rebate, órgão do Partido Democrático, um conjunto de artigos que procuravam desacreditar a luta dos proprietários aguedenses, fazendo crer que o conflito não passava de uma questão de interesse particular da parte de alguns monárquicos.

${ }^{63}$ Soberania [...], 9 de Fevereiro de 1924. 


\section{Anexo I}

MAPA: MINAS DAS TALHADAS. PERCURSO

DOS RIOS ÁGUEDA E ALFUSQUEIRO

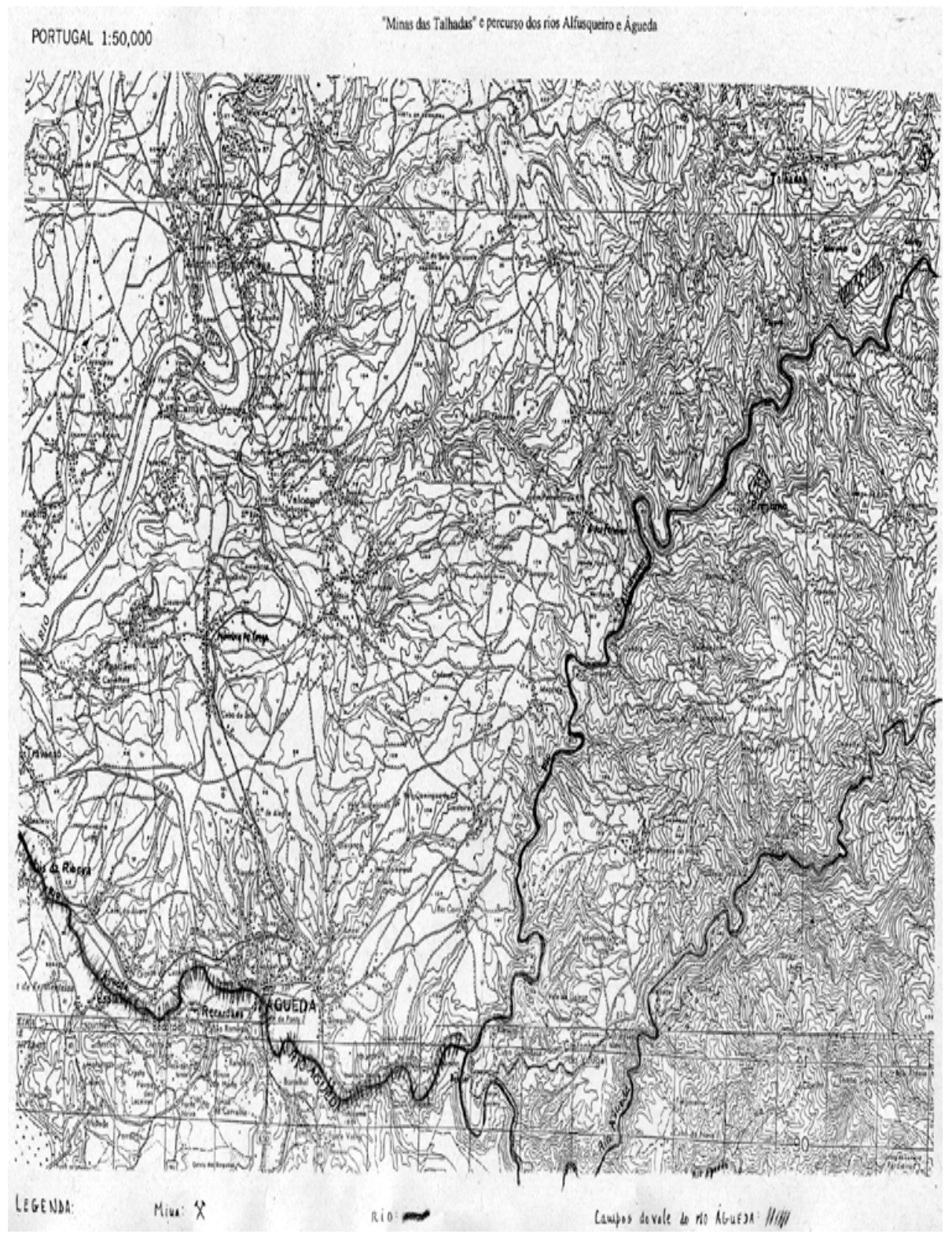


Anexo II

VISTA PARCIAL DO EDIFÍCIO DA LAVARIA (1918)

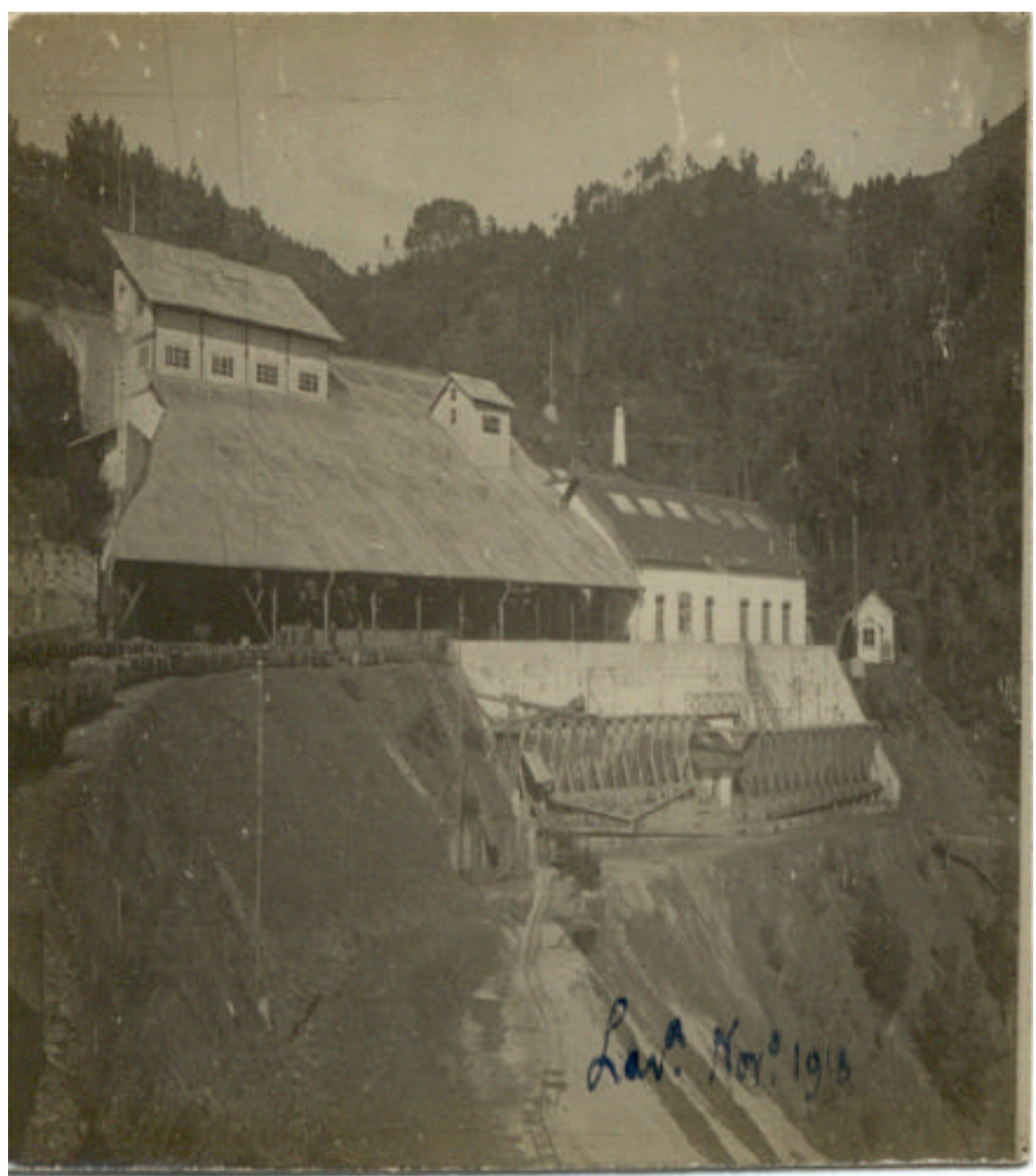




\author{
Anexo III \\ PANFLETO ANUNCIANDO O COMÍCIO DE \\ 3 DE FEVEREIRO DE 1924
}

\title{
AO POVO!
}

As aguas venenosas das Minas das Talhadas exterminaram o peixe dos rios Agueda e Alfusqueiro e já văo matando tambem o peixe do rio Vouga;

impedem que estes rios se repovôem;

impedem a producção de feijăo e abobora e a abundancia de pastagens nos nossos campos;

impedem que os nossos campos tenham a sua antiga fertilidade, sendo necessarias, para que haja uma producção regular de milho, estrumaçóes abundantes e a correcçáo da acidez dos terrenos pela applicaçāo de cal e de adubos quimicos apropriados-n que torna a cultura dispendiosissima;

Aquellas aǵuas damninhas arrastam para os campos areias finas que, n'uns pontos, alastram e, n'outras, se amontóam, tornando-os improductivos.

Todos estes damnos veem sendo causados impunemente! Desde ha muito a Companhia das Minas das Talhadas encontra sempre meio de se esquivar á indemnisação dos prejuizos enormes que ella tem feito sofirer a esta regiāo.

E' necessario que formulemos bem alto os nossos protestos e as nossas reclamaçóes, para que essa Companhia nos oiça e o Governoe o Parlamento nos attendam.

Vimos, por isso e para este fim, convocar n povo a um comicio, que se realisará no proximo domingo, 3 de Fevereiro, na Praça Gonde de Sucena, d'esta villa, ás 2 horas da tarde.

\section{Defendamos os nossos sagrados interesses! Ao comicio !}

Agueda, 29 de Janeiro de rg24.

\author{
Conde da Borralha \\ Di. Antonio Breda \\ Dr. Antonio Homem de Mello \\ Dr. Antonio Tavares da Silva \\ Armando Castella \\ Dr. Eugenio Ribeiro \\ Dr. Fernando Ferreira Baptista \\ Dr. Jayme Ribero \\ Dr. João Elysio Sucene \\ Joâo da Silva Neto. \\ Nós temos sido desdenhados,
}

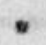




\section{FONTES E BIBLIOGRAFIA}

\section{I - FONTES}

Não impressas

Escrituras públicas de minas desactivadas.

Processos relativos às minas de Cabeço da Macieira ( $\left.n^{\circ} 227\right)$, Vale do Bicho ( $\left.n^{o} 246\right)$, Avide ( $n^{o}$ 568), Vilarinho ( $\left.n^{\circ} 569\right)$, Porto de Vilarinho ( $\left.n^{\circ} 1441\right)$, Lomba da Fonte da Serra $\left(n^{\circ} 1438\right)$ e Vale do Vau $\left(n^{\circ} 1440\right)$.

$\underline{\text { Legislação }}$

Diário do Governo

Imprensa periódica

Soberania do Povo

Independência de Águeda

Povo de Águeda

Fontes impressas

ACKERMANN, E., Le Portugal Moderne. Étude intime des conditions industrielles du pays, 2 vols., Rixheim, 1907

CAMPOS, Ezequiel (1913), A conservação da riqueza nacional, Porto.

RODRIGUES JUNIOR (1921), Manuel, A indústria mineira em Portugal: estudo económico-jurídico, Coimbra.

NASCIMENTO, Manuel (1944), Mineiros, Porto.

POINSARD, Leon (s/d), Le Portugal inconnu, 2 Vols., Paris.

Relatório dos trabalhos da comissão técnica nomeada para estudar os efeitos das águas das Minas do Vale do Vouga nas culturas dos campos marginais do Águeda e do Alfusqueiro em 1915, as causas dos prejuízos verificados e a sua avaliação, (1916), Coimbra, Imprensa da Universidade.

\section{II - BIBLIOGRAFIA}

ACKERMANN, E., Le Portugal Moderne. Étude intime des conditions industrielles du pays, 2 vols., Rixheim, 1907

ALARCÃO (1987), Jorge, Introdução à história e património locais, «Cadernos de Arqueologia e Arte», 2, Coimbra, Instituto de Arqueologia.

ALMEIDA, Pedro Tavares de (1991), Eleições e caciquismo no Portugal oitocentista, 1868 - 1890, Lisboa, Difel.

CABRAL, Manuel Villaverde (1976), O desenvolvimento do capitalismo em Portugal no século XIX, Porto, A Regra do Jogo. 
Agricultura e mineração, uma coexistência difícil. As minas do Vale do Vouga e as comunidade do Vale do Rio Águeda, 1889-1924

CABRAL, Manuel Villaverde (1979), "A Grande Guerra e o sidonismo - (esboço interpretativo)", Análise Social, no 58, p. 373 - 392.

CABRAL, Manuel Villaverde (1988), Portugal na alvorada do século XX: forças sociais, poder político e crescimento económico de 1890 a 1914, Lisboa, Editorial Presença.

CASTRO (1975), A economia portuguesa do século XX (1900 - 1925), Lisboa, Ed. 70.

CASTRO (1976), A Revolução Industrial em Portugal no século XIX, $3^{\mathrm{a}}$ ed., Porto, Limiar.

CATROGA, Fernando (1991), O republicanismo em Portugal da formação ao 5 de Outubro de 1910, Coimbra, Faculdade de Letras, 2 vols.

COSTA, Mendes (1931), O ensino elementar de minas em Portugal, Porto, Tipografia Progresso.

COSTA, Mendes (1943), Topografia mineira, Porto, Ed. Domingos Barreira.

COSTA, Mendes da (1949), Os minerais e as rochas úteis, Porto, Ed. Domingos Barreira.

CRUZ, Raul da (1987), Industrialização em meio rural: o caso de Águeda, Lisboa, Fundação Calouste Gulbenkian.

GARCIA, João Carlos, A navegação no baixo Guadiana durante o ciclo do minério, vol. I, Porto, 1996 ( Tese de Doutoramento)

GRAÇA, Serafim Soares (1988), Águeda Antiga, Águeda,.

GUIMARÃES, Paulo (1989), Industria, mineiros e sindicatos, Lisboa, I.C.S.

GUIMARÃES, Paulo (1994), Indústria e conflito no meio rural: os mineiros alentejanos dos finais da Monarquia ao Estado Novo, Lisboa (dissertação de mestrado, polic.).

HOMEM, A. Carvalho (1989), A ideia republicana em Portugal - o contributo de Teófilo Braga, Coimbra, Livraria Minerva.

HOMEM, A. Carvalho (1991), A propaganda republicana, 1870 -1910, s/l.

JUSTINO, José David (s/d), A formação do espaço económico nacional. Portugal 1810-1913, Lisboa.

LEAL, Transmontano (1942), Minérios e minas, Lisboa.

LOPES, Fernando Farelo (1990), "Um regime parlamentarista de partido dominante", in Portugal Contemporâneo, org. de António Reis, Lisboa, Alfa, vol. III.

LOPES, Fernando Farelo (1991), "Clientelismo, 'crise de participação' e deslegitimação na I República", Análise Social, no 111, Lisboa.

LOPES, Fernando Farelo (1994), Poder político e caciquismo na I República portuguesa, Lisboa, Editorial Estampa.

MATOSO, José, (dir.) (1994), História de Portugal, Lisboa, Círculo de Leitores, vol. VI.

MARQUES, A. H. de Oliveira (1981), Guia de história da Primeira República, Lisboa, Editorial Estampa.

MARQUES, A. H. de Oliveira (1991), Portugal da Monarquia para a República - Nova História de Portugal, sob a direcção de Joel Serrão e A. H. Oliveira Marques, vol. XI, Lisboa, Editorial Presença. 
MEDEIROS, Fernando (1978), A sociedade e a economia portuguesas nas origens do salazarismo, Lisboa, A Regra do Jogo.

MENDES, J. M. Amado (1980), "Sobre as relações entre a indústria portuguesa e a estrangeira no século XIX", in Análise Social, n 16.

MENDES, J. M. Amado (1984), A área económica de Coimbra: estrutura e desenvolvimento industrial, 1867-1927, Coimbra, Comissão de Coordenação da Região Centro.

MENDES, J. M. Amado (1993), "Etapas e limites da industrialização", in História de Portugal, direcção de José Matoso, Lisboa, Círculo de Leitores, vol. V.

MENDES, J. M. Amado (1998), “Cabo Mondego (Figueira da Foz): Exploração mineira e indústria”, sep. Arqueologia Industrial, $3^{\text {a }}$ Série, Vol. II, no 1-2.

MÓNICA, Maria Filomena (1986), Artesãos e operários. Indústria, capitalismo e classe operária em Portugal (1870 - 1934), Lisboa, I.C.S.

NUNES, J. P. Avelãs (1996), “A «corrida ao volfrâmio» no período da Segunda Guerra Mundial (1933-1953); Mineração do volfrâmio e problemática do desenvolvimento regional", Portugal e as Regiões: Perspectivas Históricas, Comissão de Coordenação da Região Centro, Coimbra, p. 157-177.

NUNES, J. P. Avelãs (1999), "Arqueologia industrial e museologia da mineração do volfrâmio: Uma abordagem introdutória”, Gestão e Desenvolvimento, $\mathrm{n}^{\circ} 8$, p. 233-256.

NUNES, J. P. Avelãs, "Volfrâmio e ouro do Terceiro Reich durante a Segunda Guerra Mundial (1939 - 1947)" [aguarda publicação].

OLIVEIRA, J. M. Santos (1997), "Alguns reflexões com enfoque na problemática dos riscos ambientais associados à actividade mineira", Estudos Notas e Trabalhos, IGM, Tomo 39, p. 3-25.

PEREIRA, Miriam Halpern (1971), Livre câmbio e desenvolvimento económico: Portugal na segunda metade do século XIX, Lisboa, Cosmos.

PEREIRA, Miriam Halpern (1979), Portugal no século XX - Revolução, finanças, dependência externa, Lisboa, Sá da Costa.

RAMOS, Deniz de (1989), Águeda, Anos 20: Da escola primária superior à escola comercial e industrial, Águeda, Câmara Municipal de Águeda.

REIS, António, (coord.) (1992), Portugal Contemporâneo, Lisboa, Alfa, vol. III.

REIS, Jaime (1993), O atraso económico português, 1850-1930, Lisboa, Imp. Nac.

REIS, José (1989), Os espaços da indústria: a regulação económica e a mediação local numa sociedade semi-periférica, Coimbra (dissertação de doutoramento, polic.).

ROCHA, Idorindo Vasconcelos (1997), O carvão numa economia nacional. O caso das Minas do Pejão, Porto (dissertação de mestrado, polic.).

ROMANO, Manuel (1986), "História local e regional. Que perspectivas? Que objectivos?", O Estudo da História: Boletim [dos Sócios] da Associação de Professores de História, II série, $\mathrm{n}^{\circ}$ 1, p. 78-83. 
ROSMANINHO, Nuno, "História local. O exemplo de Anadia", in Aqua Nativa, ${ }^{\circ}$ 1, Dezembro de 1991 e n 2 , Junho de 1992.

ROSMANINHO, Nuno (1993), Anadia durante a Primeira República (1910-1926), Anadia, Casa Rodrigues Lapa.

SALAZAR, A. de Oliveira., "Alguns aspectos da crise das subsistências", Boletim da Faculdade de Direito de Coimbra, t. IV, 1917-1918.

SOBRAL, José Manuel e ALMEIDA, Pedro Tavares (1982), "Caciquismo e poder político. Reflexões em torno das eleições de 1901", Análise Social, n 72-73-74, Lisboa.

TELO, António José (1980), Decadência e queda da I República portuguesa, Lisboa, A Regra do Jogo, 2 vols.

TELO, António José (1994), Economia e império no Portugal contemporâneo, Lisboa, Edições Cosmos.

TELO, António José (1977), O sidonismo e o movimento operário português - A luta de classes em Portugal, 1917 - 1919, Lisboa, Biblioteca Ulmeiro.

VALENTE, Vasco Pulido (1980), "Estudos sobre Sidónio Pais: Comércio e distribuição em 1918", in Estudos sobre a crise nacional, Lisboa, Imp. Nac., p. 293 e ss.

VALENTE, Vasco Pulido (1976), O poder e o povo: A revolução de 1910, Lisboa, Morais Editores.

VILAR, António (1998), O Volfrâmio de Arouca, Câmara Municipal de Arouca, Arouca. 